NBER WORKING PAPER SERIES

\title{
JAPAN'S ULTIMATELY UNACCURSED NATURAL RESOURCES-FINANCED INDUSTRIALIZATION
}

\author{
Randall Morck \\ Masao Nakamura \\ Working Paper 22865 \\ http://www.nber.org/papers/w22865 \\ NATIONAL BUREAU OF ECONOMIC RESEARCH \\ 1050 Massachusetts Avenue \\ Cambridge, MA 02138 \\ November 2016, Revised July 2017
}

\begin{abstract}
We are grateful for helpful comments at the American Economic Association, National University of Singapore, Weseda University and the World Bank. We are especially grateful for helpful suggestions from Katsuyuki Kubo, Hideaki Miyajima, John P. Tang and Bernard Yeung. Randall Morck gratefully acknowledges partial funding from the Bank of Canada and from the Social Sciences and Humanities Research Council of Canada (SSHRC). Masao Nakamura also acknowledges partial research support from the SSHRC. The views expressed herein are those of the authors and do not necessarily reflect the views of the National Bureau of Economic Research.
\end{abstract}

NBER working papers are circulated for discussion and comment purposes. They have not been peer-reviewed or been subject to the review by the NBER Board of Directors that accompanies official NBER publications.

(C) 2016 by Randall Morck and Masao Nakamura. All rights reserved. Short sections of text, not to exceed two paragraphs, may be quoted without explicit permission provided that full credit, including $\odot$ notice, is given to the source. 
Japan's Ultimately Unaccursed Natural Resources-Financed Industrialization

Randall Morck and Masao Nakamura

NBER Working Paper No. 22865

November 2016, Revised July 2017

JEL No. G3,N25,O14,O53,P28

\title{
ABSTRACT
}

Japan's successful industrialization in the late 19th and early 20th century largely exhausted its then abundant natural resources. Rather than exemplifying rapid development in the absence of natural resources, Japan shows how laissez-faire government and successfully transplanted classical liberal institutions, including active stock markets, exorcised a natural resources curse that undermined its prior state-led industrialization strategy. Japan's post-WWII reconstruction relied little on natural resources and more on bank financing and state direction, but was not an example of an initial industrialization.

\author{
Randall Morck \\ Faculty of Business \\ University of Alberta \\ Edmonton, AB T6G 2R6 \\ CANADA \\ and NBER \\ randall.morck@ualberta.ca \\ Masao Nakamura \\ Faculty of Commerce and Business Admin. \\ University of British Columbia \\ 2053 Main Mall \\ Vancouver, B.C.CANADA V6T 1 Z2 \\ masao.nakamura@sauder.ubc.ca
}




\section{Introduction}

Japan's initial industrialization in the late $19^{\text {th }}$ and early $20^{\text {th }}$ centuries depended heavily on natural resources. The large, family-controlled pyramidal business groups (zaibatsu), which dominated the economy throughout this era (Sugiyama, 2012, Tang, 2011, Yasuoka, 1976), each contained one or more large mining firms. Historical records show that earnings from their mining firms was critical in capitalizing their first manufacturing, financial, and services firms, and remained important in financing zaibatsu expansions until the early twentieth century, when active stock markets became a major alternative source of capital.

The theory of the natural resources curse attributes the ongoing poverty of many resource-rich developing economies to extractive elites capturing resource rents that provide them more wealth and power than would be attainable were general development to proceed (Auty 1993; Sachs \& Warner 1999). To safeguard their economic power, extractive elites can erect barriers to entrepreneurship (Farzanegan \& Reza. 2014) and divert public spending away from investment in public goods (Bhattacharyya \& Collier 2014), notably education (Cockx \& Francken 2016). Government coffers flush with resource revenues can magnify the returns to political rent-seeking (Krueger 1974), encouraging corruption, which retards development (Murphy et al. 1991, 1993). Economies can become trapped in low-level equilibria where extractive rent-seeking elites retain power by suppressing institutional development (Acemoglu et al. 2001; Rajan \& Zingales 2003). A vast literature debates, refines and links this thesis to weak institutions. ${ }^{1}$ This paper recounts how pre-industrial Japan avoided (perhaps narrowly) a

1 For surveys see Papyrakis (2017) and van der Ploeg \& Poelhekke (2017). Boianovsky (2013) traces the resources curse to Hume and Mill. This literature, too vast to fully, provides support (e.g. Baland \& Francois 2000; Auty 2001; Torvik 2002; Drehlichman 2005; Robinson et al. 2006; Mavrotas et al. 2011; Busse \& Gröning 2013; Ross 2014; Cust \& Poelhekke 2015; Gilberthorpe \& Papyrakis 2015; Mendoza et al. 2015; Sachs \& Warner 1999, 2001) and criticism (e.g. Haber \& Menaldo 2011; Arezki \& van der Ploeg 2011; Bjorvatn et al. 2012; Cotet \& Tsui 2013; Davis 2013; James 2015; Smith 2016 2015; Havranek et al. 2016 mssing). Robust results tend to stress weak institutions (Davis 1995; Mehlum et al. 2006; Robinson et al. 2006; Humphries et al. 2007; Ross 2011; Brückner 2010; Williams 2011; Alkhater 2012; Andersen \& Aslaksen 2013; Boschini et al. 2013; Tores et al. 2013; Buonanno et al. 2015; Elbadawi \& Soto 2015; Bodea et al. 2016; Hasalam 2016; Matheis 2016). Earlier work on British colonies of settlement also link primary sector earnings to institutional development and hence economic growth (Innis 1923, 1930, 1940, 1956; Ville \& Wicken 2013; Keay 2015). Holden (2013) describes Norway in similar terms. Non-exclusive alternative theses include elevated factor costs (Forsyth \& Kay 1980; Ellman 1981; Corden \& Neary 1982; Torres et al. 2013; Papyrakis \& Raveh 2014; 
natural resources curse with an abrupt shift to liberal institutions. Historical evidence provides insights about how and why Japan undertook specific institutional reforms and how those redirected Japan's large natural resources sector's earnings to underwrite its rapid and highly successful economic development in the late $19^{\text {th }}$ and early $20^{\text {th }}$ centuries.

Under the cannon of American gunboats, the Tokugawa shogunate opened Japan to the outside world in 1854, ending centuries of autarky. Revolted at this humiliation, a coterie of samurai overthrew the shogunate in the 1868 Meiji Restoration. The Meiji state's first development program, launched in the 1870s, capitalized one or more large state-owned enterprises (SOEs) in each modern industry deemed essential to rapid modernization. Expecting these to lose money initially, the government dedicated revenues from SOE mining companies to subsidize the other SOEs. This policy presages mid- $20^{\text {th }}$ century Big Push development theories (Rosenstein-Rodan 1943). Despite little overt corruption, political rent-seeking and soft budget constraints quickly escalated industrial SOEs' losses far beyond mining SOEs' earnings, triggering a major financial and fiscal crisis.

To extricate Japan from this crisis, classical liberal reformers organized the world's first mass privatization, auctioning off most of the SOEs to restore public finances. Once burned, Japan's leaders embraced Victorian laissez-faire economics from the 1880s until the military takeover in the 1930s, and largely restricted further public investment to education, law, and other institutional and physical infrastructure necessary to support a market economy.

A mixture of venerable merchant families and foreign-trained entrepreneurs ultimately acquired most ex-SOEs, which became the nuclei of their zaibatsu. These business groups then set about doing what the state could not - using earnings from their "cash cow" mining firms to capitalize and expand firms in other sectors necessary to the group's overall financial health. Only as the $20^{\text {th }}$ century dawned did share issues displace resource earnings as their primary source of new capital. Morck and Nakamura (2007) argue that the zaibatsu controlling shareholders successfully coordinated a Big Push industrialization program of the sort Rosenstein-Rodan (1943), Murphy et al. (1989) and others call for governments to implement.

Guilló \& Perez-Sebastian 2015), unsustainable consumption (Rodriguez \& Sachs 1999) and skewed investment (Alichi \& Arezki 2012). 
By the 1920s, Japan was an industrialized economy on par with much of Europe. ${ }^{2}$ How did Japan evade the natural resources curse? First, a resolute commitment to laissez-faire economics, by drastically curtailing the scope of state intervention in the economy, likely greatly lowered the returns to lobbying politicians and government officials for subsidies, tax breaks, and the like. Low returns to political rent-seeking left importing and applying foreign technology the most profitable investment on offer. We argue that this was because memories of the financial crisis sustained support for Victorian liberalism. Second, although the era was not scandal-free, corruption on the scale evident in many resource-rich developing economies today was not apparent. Genuine political competition and very high pay levels for government officials are also plausible factors. The factions eagerly denounced each other for any hint of corruption, and the high salaries meant government officials had much to lose. Thus, the return on rent-seeking may well have been lower than the return on investment in property, plant and equipment or technology.

\section{Pre-modern Japan's Abundant Natural Resource Wealth}

Gold, silver, copper and sulfur mines loomed large in $16^{\text {th }}$ century. Hideyoshi Toyotomi (15361598), whose usurpation of power led to the Tokugawa Shogunate, declared all mineral wealth state property. The Shogunate directly controlled major mines, delegating lesser ones to feudal lords via revenue sharing schemes. This policy continued until the Meiji era.

The first Tokugawa Shogun, Iyesayu (1543 - 1616), imported Spanish mining engineers to improve existing mines and prospect for new ones. This effort established copper mines at Ashio (1610), Okosawa (1666), and perhaps most importantly, the Besshi copper mines (1690), whose management the Shogun entrusted to the Sumitomo family from 1691 on (Japan Oil, Gas and Metals National Corporation, 2006).

Thus, Japan's copper mines grew from 23 in 1668 to 50 in 1684-1687, and produced 1,250 tons of unrefined copper per year in the latter period. The Ashio mines yielded an average of 812 tons per year from 1610 through 1759, and the Sumitomo's Besshi copper mine

\footnotetext{
2 Japan's post-WWII growth, which occurred in the absence of significant natural resource wealth, is the reconstruction of a pre-existing industrial economy, and probably should not properly be regarded as a case of economic development.
} 
averaged about 558 tons of copper per year from 1691 through 1867 (Japan Oil, Gas and Metals National Corporation, 2006; also Flynn and Giraldez, 2002).

[Table 1 about here]

Table 1 clarifies the economic significance of these magnitudes by contrasting the total copper output of Japan in different periods with those of England and Chile, major contemporaneous producers. Complete historical data are unavailable, but Table 2 presents a decade-by-decade comparison with copper output from Sweden, yet another major producer of this era.

[Table 2 about here]

Both the Ashio and Beshi mines peaked near the beginning of the $18^{\text {th }}$ century, and their output was slowly declining until the Meiji era - primarily because flooding limited their depth. The third Tokugawa Shogun, Iyemitsu Tokugawa (1604-1651), proscribed contact with foreigners in 1639. This ban lasted for two centuries until Admiral Perry's arrival; but excepted the copper exports to the Netherlands and China described in Table 2. Copper exports to Holland passed through Dejima Island, a hermetic Dutch enclave on in Nagasaki harbor, and Japanese copper was a major part of the Dutch East Indies Co. (VOC) Asia trade. Japan's copper exports to China went through approved Chinese merchants.

By the late $17^{\text {th }}$ and early $18^{\text {th }}$ centuries, Japan's gold and silver mines deteriorated to the point where the country began importing silver and then gold from China, and then the VOC. Thus, from 1769 to 1800 , Dutch silver coins worth about ff1M entered Japan; while the Dutch bought Japanese copper worth about ff8M. Silver and gold imports from China were likely much larger. Throughout this era, the Japanese government obdurately priced copper and gold at about $50 \%$ and $33 \%$ of their contemporaneous world prices in silver. The ensuring textbook arbitrage opportunity, while offering potentially boundless profit, was constrained by capital punishment for illegal foreign trade (Shimada 2006). From the late $18^{\text {th }}$ century on, growing numbers or Western ships nonetheless lingered in the seas around Japan. Foreign

3 The VOC (Vereenigde Oost-Indische Compagnie; lit. United East Indian Co; commonly known in England as the Dutch East Indies Co.), established in 1602 to import spices from the East Indies (Indonesia), was the modern world's first joint stock company. The company rapidly grew to trade in a wide range of commodities, and was, for a time, a major force in global political and economic events. 
intervention to end Japan's isolation, though volubly justified by the instant execution of shipwrecked sailors washing up on Japan's coasts, plausibly also reflected perceived arbitrage profits in precious metals trading. The treaty Commander Perry extracted opened the ports of Shimoda, Yokohama and Hakodate to American trade in 1854. Foreign traders could now legally arbitrage the difference in precious metals prices, and a massive outflow of gold ensued amid much exuberance about Japan's mineral wealth.

Reconnection with the outside world let the Japanese adopt new pumping technology that helped the mines' output rebounded to new highs. The Tokugawa government asked Townsend Harris, the first U.S. Consul General to Japan, to send geologists to modernize Japan's mines. Two U.S. geologists, Raphael Pumpelly ${ }^{4}$ and Willian Blake ${ }^{5}$ arrived in Hakodate, in Hokaido, in February 1862; and spent the next year assessing Japan's mineral resources, including its coal deposits. While in Japan, they also trained students in mining engineering and natural sciences - for example, showing them how to use gunpowder to rejuvenate the Yurappu lead mine, which produced lead for bullets and continued operating until 1970. Their students subsequently became major players in Japanese mining (Murakami, 2007).

Pempelly proposed three major technological innovations to reverse the long-term downward trend in mining output: explosives to expand mines, steam-powered pumps to keep deep passages from flooding, and vertical shafts. After the Meiji restoration, these reforms were implemented, and Japan's minerals production surged to new heights. This dependence of modern mining industry on other sectors - chemicals and industrial machinery - also became apparent.

\section{The Natural Resource Curse and its Exorcism in Japan}

The samurai heading the 1868 Meiji Restoration seized power to purify Japan of foreign influence. Once in power, they understood that this goal would require an intermediate step. Defeating foreigners would require replicating foreign weapons, which would require critical

\footnotetext{
${ }^{4}$ Raphael Pumpelly (1837-1923) was a Harvard professor and President of the Geological Society of America.

${ }^{5}$ William Phipps Blake (1826-1910) received a Ph.D. from Yale's Sheffield Scientific School in 1852.
} 
modern industries. ${ }^{6}$ The 1871 Iwakura Mission, a group of key Meiji leaders around the world to observe foreign ways, returned with an assessment of Japan's relative backwardness that so shocked the Meiji samurai that they resolved that Japan would have to change. Young Japanese sent abroad to study foreign science, law, economics, and engineering; and to observe foreign courts, economies, and governments returned with reports that brought institutional change unparalleled in scope and depth until the shock therapy post-socialist reconstructions in 1990s Eastern Europe. The expression shock therapy, coined in that context by Sachs (1990), seems perhaps more apt here.

Meiji Japan's shock therapy, like its 1990s namesakes, was a comprehensive and simultaneous reform of all institutions. Within a few years, Japan had a democratic legislature modeled on the German Diet, public schools modeled on those of France and Germany, universities modeled on those of Germany, and Prussian-inspired army, and a British-inspired navy; all while it enshrined religious freedom, legitimized social mobility, and broke up feudal estates in a comprehensive land reform.

Remarkably, the Meiji reformers, all samurai of different ranks, concluded that hereditary casts and a warrior ethos were hopelessly at odds with modernization; and ended all feudal ranks and privileges in 1871. Japan's feudal system had united its society, so a new binding agent was needed. Using the German Civil Code as a template, with modifications and with grafts from other legal models, Japan erected a new state-of-the-art late $19^{\text {th }}$ century legal system. By the early 1870s, regulations governed public bond issues, and the 1878 Stock Exchange Ordinance allowed modern stock markets to rise in Tokyo and Osaka. By 1888 Japan's Civil Code was easily as sophisticated as its German archetype.

\subsection{A State-led Natural Resources Financed Big Push}

The government's goal was still industrial munitions plants, naval shipyards, and the like. No private sector businesses seemed remotely up to the task. Two Tokugawa era business families, the Mitsui and Sumitomo, adopted foreign technology, but only to upgrade their traditional businesses, silks and copper, respectively. Their new banking and trading units were merely

\footnotetext{
${ }^{6}$ This section draws heavily on Morck and Nakamura (2005), who provide more detail on these events.
} 
supportive of their traditional business. Other Tokugawa business families, notably the Shimomura and Ohmura, floundered and ultimately faded away.

The State therefore took the commanding heights, establishing SOEs to import and apply foreign technology to modernize the military. The last Tokugawa Shogun had tentatively started down this path, so the Meiji leaders inherited a set of armaments and munitions SEOs, which they put under military control. Yokosuka ironworks, Yokohama ironworks, Uraga shipbuilding, and Ishikawajima shipbuilding went to the navy; Sekiguchi manufacturing went to the army. Prominent Tokugawa lords, anxious to modernize their military capabilities, had also established munitions plants. The Meiji rulers expropriated these, delivering the Shikine gun powder plant and Shuseikan manufacturing complex to the navy and the Takinokami gun powder plant and Ogi Chuzou metal casting plant to the army.

It quickly became apparent that, like modern mining operations, modern munitions plants depended on other industries. New SOEs in railroads, merchant shipping, and infrastructure construction ensued. The Meiji government clearly understood it needed a Big Push, for it rapidly established new SOEs in every modern industry. These were large and costly ventures in modernized coal mining, machinery, chemicals, and textiles. In machinery and chemicals, the Meiji government established Akabane seisakusho, Cement seizosho, Shingawa glass seizosho, and Shirorengaishi seizousho. In cotton, textiles, and clothing, key stateestablished ventures included Tomioka seishisho, Shinmachi Bousekisho, Senju seijusho, Aichi bosekisho, and Hiroshima bosekisho. The Ministry of Industry set up yet more SOEs in mining, railways, civil engineering, telegraphy, navigation, shipbuilding, iron production, and manufacturing while executing a master plan for the dotting Hokkaido with SEO cotton mills, breweries, dairy products plants, canneries, sugar refineries and other ventures. Hyogo shipbuilding, seized from a Tokugawa lord, also went to the Ministry of Industry.

The Ministry of the Interior was charged with control over general commerce, vital statistics, the post office, cartography, land surveys, and the police; and given a budget for civil engineering projects. Railroad SOEs were quickly set up for moving goods, but the Meiji leadership also saw how they could connect previously isolated regions into a national economy, and ordered additional lines between remote interior regions and open ports. 
Ordered to make the country as self-sufficient as possible, the Interior Ministry set up SOEs related to agriculture, forestry, textiles, pulp and paper, maritime shipping, and other sectors. Its control over policing and regional matters involved the ministry in local affairs, and in numerous small-scale SEOs throughout the country: experimental agricultural stations, farm factories, and dairy farms - many on very small local scales. But it also set up large-scale SOEs in agriculture, dairy products, and food mass production.

The Ministry of Agriculture also established larger SOEs in industries connected with food supplies (Kobayashi (1977, Ch.4); and the Sakai textiles plant, seized from a Tokugawa lord, went to the Ministry of Finance.

The government expected many, perhaps most of these SOEs to lose money for many years, and planned on using revenues from SOE mining companies to subsidize them. An 1873 mining law declared all underground minerals state property - effectively expropriating the many mines owned by Togugawa warlords. To supplement these, the government would rely on the many new SEO mines built around discoveries by Pumpelly and Blake and their students.

Japan's only modernized Tokugawa era coal mine, the Takashima mine near Nagasaki, was owned by the Dutch merchant T.B. Glover, albeit with Japanese partners. ${ }^{7}$ MacMaster (1963, p. 17) holds that "The influence of Takashima as a successful pilot model [for] ... other Japanese mining projects is inestimable." But, having foreigners run the mine embarrassed the Meiji rulers, and likely motivated the 1873 mining law. Threatening expropriation, the government bought the Takashima mine for $¥ 400,000$ in 1874 . At the time, this seemed generous and the reformers were denounced for currying foreign favor. The politicallyconnected merchant, Shojiro Goto, stepped forward later that year to purchase the mine for $¥ 550,000$, presenting the government with a $¥ 150,000$ profit.

The Ministry of Industry ran ten large SEO mines, and contracted the management of the rest, often to political cronies like Goto. All revenues generated by the directly-run mines accrued to the state, and royalty sharing agreements governed the others. Figure 1 shows the fraction of natural resources output from state-run mines and privately-managed SOE mines.

[Figure 1 about here]

\footnotetext{
${ }^{7}$ In 1888, Mitsui began modernizing the huge Miike coal mine located in Northern Kyushu.
} 
These policies are recognizably analogous to the Rosenstein-Rodan's (1943) prescription for a state-led Big Push industrialization program to orchestrate rapid industrialization. In making the case that rapid industrialization requires extensive state control over the economy, he notes that every firm in an advanced industrial economy relies on the mere existence of countless other firms, scattered throughout the economy, most of which have no direct business with it. Each firm depends on a far-reaching network of suppliers, and those depend on yet more suppliers and their suppliers. Complementarities across different sets of products add yet more interdependencies. A steel firm depends on cement makers not because they provide it inputs or buy its output, but because construction firms need both concrete and steel. State subsidies are needed for firms forced to operate at inefficient scales until other sectors, to which they are essential, expand. State control over prices is needed to prevent "hold-up" problems, where a firm with a monopoly position in a value chain extracts profits from its suppliers and customers by threatening to withhold business. Finally, noting that solving all these problems requires a single controlling entity capitalizing and coordinating the actions of firms in many diverse sectors, Rosenstein-Rodan sees no alternative to comprehensible state control because (p. $\mathrm{xx}$ ) "No private sector mechanism exists that can simultaneously plan the industrialisation of several complementary industries". Sophisticated economic models verify Rosenstein-Rodan's intuition by formalizing the ways in which this litany of coordination problems impedes economic development (Murphy et al. 1989).

Rosenstein-Rodan (1943) christens such a state-planned, SOE-led, economy-wide rapid industrialization a Big Push. After World War II, the World Bank was formed largely to implement Big Push development plans throughout the Third World. By the 1930s, Japan had become a highly centralized and militarized state-led economy, so its rise to world power status seemingly affirmed the importance of state-control in quickly transforming a traditional economy into a modern one.

Indeed, the early Meiji government's plan to expand mining output, capitalize a flock of state-owned enterprises, and empower government officials to coordinate their operation to achieve economy-wide industrialization is precisely the sort of state-coordinated Big Push that Rosenstein-Rodan inspired throughout the world in the mid- $20^{\text {th }}$ century. Moreover, the 
Interior Ministry's charge, to make the country as self-sufficient as possible, even presages the import substitution development agendas of the 1950s and 1960s (Prebisch, 1959). To a remarkable extent, mid-twentieth century development economics recapitulates the policies of early Meiji Japan.

\subsection{Government Failure}

Meiji Japan soon encountered the same government failure problems that discredited these policies in the $20^{\text {th }}$ century. The SOEs quickly ran up losses far beyond their worst expectations, and the state's mining revenues fell far short of the challenge. The SEO mines whose management was contracted out were especially disappointing, never providing more than $0.1 \%$ of the state's revenues. To raise more revenue, the government undertook a comprehensive tax reform in 1873, abolishing the peasants' traditional rice tax to their feudal lords and requiring taxes to be paid in coin and directly to the central government's tax collectors. This revenue, plus earnings from the expanding mining sector, restored the government's operating budget through 1875.

But the rapidly expanding industrial SOEs, virtually without exception, ran up rapidly deepening losses. It seems likely that this was because individual SEOs lacked budgets. Rather, each ministry had a mission, a budget, and full responsibility for all its SEOs' losses. This was not merely a "soft budget constraint", of the sort reformers in 1990s Eastern Europe sought to harden. Individual SOEs quite literally had no budget constraints at all, for all their losses were entirely collective. Each SOE top manager thus confronted a classic free-rider problem, and a strong incentive to run up losses faster than other SEOs under the same ministry.

To contend with existing SOE losses and launch yet more new ones, the Meiji reformers began issuing bonds. The first issue, $£ 1$ million at $9 \%$ raised in London in 1870, financed SOE railways. ${ }^{8}$ A second London issue in 1873 raised a $£ 2.4$ million more, this time at only at $7 \%$, to pay former feudal lords and samurai their allowances - one third to one half of the state's overall budget. The government then ended these allowances, giving their recipients yet other government bonds 1876, freeing up funds from the second London issue to underwrite more

\footnotetext{
${ }^{8}$ At this time, the yen was at parity with the American dollar, and one pound was $¥ 4.85$.
} 
SOEs.

In the late 1870 s, the government took to lending directly to private-sector banks and firms to finance industrialization. Some borrowers were associated with future zaibatsu Mitsui Bank received almost $¥ 11$ million in government loans. Mitsui Bussan received another $¥ 625,000$, and the Mitsubishi head office almost $¥ 2.5$ million, both largely to develop their shipping businesses. In total, nearly $¥ 42$ million went to banks, nearly $¥ 8$ million went to nonfinancial firms and another $¥ 4$ million went to individuals (Akimoto, 2004; Sugiyama, 2012; Ishii, 1992, p. 11).

Government debt was nothing new in Japan, for the shoguns traditionally extracted loans from wealthy merchants. These were always secret, so noble samurai would not be seen dealing with socially despicable merchants. The Meiji reformers were now borrowing openly from foreign merchants, so formal debts to domestic merchants no longer seemed beyond the pale. From 1872 through 1883 , a series of debt issues to domestic investors raised $¥ 292$ million - about seven times the state's total annual budget in a typical year.

In 1877 , the reformers needed even more money to put down a rebellion by disgruntled traditionalists. They had created a long sequence of numbered national banks empowered to print inconvertible bank notes, and borrowed another $¥ 15$ million from the $15^{\text {th }}$ of these. Still short and desperate to end the uprising, the government printed $¥ 27$ million in inconvertible paper currency, mobilized a larger military force and put down the rebellion.

The government and the numbered banks were now all printing fiat paper. The first four national banks, established in 1873 , were empowered to issue paper money fully backed by gold. Their inability to guarantee convertibility, plus the state's need to print more money, led the government to relax and then abandon the convertibility requirement. This, along with relaxed entry, created a collective action problem- each bank profited by printing money faster than the others; and inflation accelerated rapidly from 5\% in 1878 to $9 \%$ in 1879 to $14 \%$ in 1880 . By 1881, prices were 62\% above 1873 levels. High inflation was not only unpopular, but also made the government's huge pound-denominated debts increasingly unmanageable. A major financial crisis developed: inflation was out of control and London markets no longer welcomed Japanese bonds. 


\subsection{Liberalization}

The Meiji Finance Minister, Masayoshi Matsukata, resolved to conquer inflation and restore fiscal stability, launched a set of reforms in the early 1880s that remarkably presaged the liberalizations of the late $20^{\text {th }}$ century.

Matsukata's monetary reform unified the currency. The numbered national banks and the state could no longer print paper money; only the Bank of Japan could, and its yen would be backed by silver from 1886 until 1897 and gold thereafter. This rebuilt trust in the yen and brought seniorage fully into the government's revenue stream. Inflation went negative in the early 1880 s, bottoming out at $-19 \%$ in 1883 . By 1886 , prices were down to only four percent above their 1873 levels.

Lasting reform requires stopping the SEO money sink. This necessitated a fundamental change in development strategy - forsaking state-led development and embracing of $19^{\text {th }}$ century liberalism. From 1878 on, each SOE had to provide a budget and balance sheet using Western accounting principles. This exercise allocated specific assets to specific SOEs - a process dubbed corporatization in post-Cold War Eastern Europe (Lipton and Sachs 1990). It also bound managers to the fortunes of their SOEs by isolating losses in the SEOs that ran them up, ending the free-rider problems of the previous system of ministry-level accounting. Corporatization also clarified which SEOs were the worst loss generators, and so undercut their lobbying power.

Matsukata cut subsidies slowly at first, and lobbying protected maritime shipping, railways, and silk from any cuts for a time. But, as fiscal reality sunk in, the Meiji reformers accepted universal and deeper cuts, and finally a total moratorium on new SOEs. The deep subsidy cuts inflicted hard budget constraints on the SEOs for the first time; and, as in the transition economies of Eastern Europe and the former Soviet Union (Shleifer and Vishny, 1994), SOE governance improved abruptly.

\subsection{Mass Privatization}

Western accounting also assigned a book value to each SOE, and these were huge, each 
including not just the state's initial investment but the sum of all subsequent (heavily subsidized) capital spending. Struggling to cope with declining budgets for basic government services, politicians began thinking about recovering these costs by selling some, or even all, SOEs to private investors.

Talk of privatization evoked counterarguments that the SOEs were never intended to be individually profitable: full-scale modernization was thought worth individual firms' losses, as in Rosenstein-Rodan (1943), Murphy et al. (1989), and Sachs (2005). But profits from some SEOs, especially the mines, were expected to pay for the losses of others. Across-the-board and seemingly unending losses were never in the cards. But even within this debate, SOE supporters had to justify benefits against a more realistic assessment of costs, including opportunity costs recoverable via privatizations.

These arguments failed to win the day, and the Meiji government set about planning a mass privatization. Because their purpose was to restore government finances, the privatizations had to be priced as high as possible. This left little scope for corruption in the form of sweetheart deals with connected buyers. The first privatization round, launched in 1880, offered fourteen large money losing SOEs for sale at their gross book values (book value with no allowance for depreciation). State official were to screen prospective buyers, not for ability or expertise, but for sufficient financial resources to guarantee continued operations (reallocating SEO assets was not to be avoided). Virtually no buyers showed, and the privatization plan stalled.

Under mounting fiscal pressure, the officials who established and subsidized the SEOs reluctantly concluded that most were not worth their gross book values. The government therefore passed a second mass privatization law in 1884, again aimed at raising money as much money as possible. This offered profitable SOEs, including mining operations, to the highest bidder. The Takashima mine, nationalized in 1874, was the model. Smarting from criticism for overpaying the mine's foreign owners when nationalizing it, the government resold it a year later to the Meiji political entrepreneur Shojiro Goto for $¥ 550,000$. This netted the government a $¥ 150,000$ profit above what it paid the mines foreign owners.

The 1884 privatization program began Japan's fiscal deliverance by repeating this 
exercise with other profitable SEO mines. Successful mine sales invited more privatizations to raise further funds, this time of industrial SOEs. By 1896, 26 major SOEs had been privatized - in coal, mining, textiles, shipbuilding, cement, iron works, sugar refining, and glass making.

[Table 3 about here]

Table 3 details the largest of the SOE sales in the mass privatization. Of the 21 major privatizations, ten were of mining SOEs, ten were SOEs in other fields and one was in both mining and railroads. The proceeds of the privatization are given in current yen and in British pounds, the era's reserve currency, because a composite price index is unavailable. ${ }^{9}$ The yen fell from $£ 0.208$ in 1874, moved in a lower range in the early to mid-1880s: $£ 0.185$ in 1882 and 83, £0.182 in 1884 and £0.173 1885), and then in a yet lower range (£0.159 in 1886 and 87, f0.153 in 1888, £0.157 in 1889), culminating in a period of volatility around an unsuccessful revaluation ( $£ 0.172$ in 1890, $£ 0.126$ in 1893 , and $£ 0.107$ in 1896).

[Table 4 about here]

Note that the proceeds the government received privatizing mines vastly exceed those from privatizing other SOEs. Table 4 quantifies this difference, showing that the government's take from mine privatization was over five times its proceeds from other major privatizations.

Table 3 also shows privatization Qs, calculated following Lopez-de-Silanes (1997), as privatization proceeds divided by book value of assets privatized. The book value of an SOE is an accounting estimate of the historical cost of all its assets - that is, the net total government's investments in the SOE over the years. A privatization $Q$ greater than one means the government got more money privatizing the SOE than it put into the SOE, after adjusting for asset depreciation. A privatization $Q$ less than one means the government got back less than it put in.

A few measurement issues arise because book values are available for most of these firms only for 1985. Consequently, the book values of SOEs privatized before 1985 are biased up by their private owners' net contributions of new capital between the privatization date and 1985. Net contributions are most plausibly positive, biasing their privatization Qs down. Book values of SOEs privatized after 1885 are likely relatively unbiased as the state had largely ceased

\footnotetext{
9 Price indexes are available for rice or other staples.
} 
further investments by then. A third bias arises from the use of historical cost accounting; which, in a period of inflation and currency devaluation, understates the real cost of older assets. This biases down the book value of firms with older assets, and so probably elevates the privatization Qs of firms privatized later. This approach also omits funds the state received as paid out earnings while the firm was an SOE. This is tolerable, as even mines lost money under state control.

Even allowing for these caveats, the differences in privatization Qs between mines and other SOEs is stark. On average, the state got its money back or better with SOE mines, but lost roughly half its net capital investment in SOEs in other sectors. Nonetheless, the variance in privatization Qs for mines is an order of magnitude larger than for other SOEs. The state reaped a more than six-fold gain privatizing the Miike Coal Mine, but lost almost everything it put into Kamaishi Iron Ore. The state's worst loss on a non-mine (Monbetsu Sugar Beets) was larger as a percentage, but smaller in yen or sterling. Non-mine privatization Qs generally fall between 0.25 and 0.75 .

Many of the SOEs were soon resold by their initial buyers. Many ultimately ended controlled by either traditional merchant houses, such as the Mitsui, who bought ex-SOEs to expand from the silk trade into mining and industry, or upstart Meiji era entrepreneurs, including the Iwasaki, who built Mitsubishi, and Aikawa, who founded Nissan. Only a few SOEs were kept. Key military suppliers, money printers, government documents printers, railways, and telegraph lines remains state-owned, as did post offices. Japan's major private railways and military equipment manufacturers arose subsequently as new firms; none were former SOEs. Military suppliers judged obsolete or unimportant were privatized, as were all other SOEs.

\subsection{Japan as a Natural Resources Superpower}

In the decades after the privatization, Japanese natural resources production soared. Japan ranked among the most natural resource-rich economies in the world - often leading Australia and Canada, and consistently trailing only the United States. Figure 2 graphs the outputs of the world's leading natural resource rich economies from 1870 to 1930.

Through most of this period, japan was the world's second largest coal producer. Panel 
A of Figure 2 shows Japan's coal production ahead of that of both the UK and Germany in 1870. Japanese production already exceeded both China's and India's when their first data become available - in 1903 and 1891, respectively. Japanese output surpassed both Australian and Canadian production in 1894. Thereafter, Japan was the second largest coal producer in the world - lagging only the US, always the largest coal producer in the world by far.

Panel B shows Japan's copper production surpassing Britain's in 1878, and already ahead of Canada, Mexico and Australia when their data for first become available in 1886, 1884, and 1890, respectively. Canadian output grew steadily, but did not overtake Japan's until the late 1920s. A period of high production brought Mexica output to roughly the same levels as Japan's from 1900 to 1913. Overall, the panel shows that Japan was the world's third largest copper producer during much of this period. Only the US, always the largest producer by far, surpassed it throughout; and Germany also led Japan by a wide margin until its output collapsed in the aftermath of World War I.

Panel $C$ shows Japan always numbering among the top ten gold producers, with the rank ranging from fourth in earlier years to seventh or eighth in later years. Panel $D$ shows Japan only among the top ten to twelve iron ore producers in the world throughout this period. Panel E shows Japan generally ranking sixth or so in silver output throughout these decades.

[Figure 2 about here]

\section{Japan's Successful Natural Resources-based Industrialization}

The government's attempt to industrialize off natural resources revenues brought the economy to its knees. Japanese remained largely poor, and its military was still no match for foreign gunboats. Thus burned, this and successive government adhered closely to Victorian laissezfaire economics, maintaining a largely "hands off" policy towards business for the next several decades. From the mass privatization through the beginning of World War II, Japan established only one more SOE was established, Yawata Steel in $1901 .{ }^{10}$ Business subsidies also remained

\footnotetext{
${ }^{10}$ The government originally hoped Misui or Mitsubishi might undertake this project, but both declined citing insufficient funds for such a major undertaking. The state then invested over $¥ 10$ million yen to establish Yawata Steel. Its stated purpose was to provide iron and steel to civilian, not military needs (Akimoto, 2004, p.12).
} 
tiny - averaging only $1.7 \%$ of the government budge from 1890 to 1904 and only one percent in the early $20^{\text {th }}$ century (1900 to 1936) (Miyajima 2004). Indeed, subsdidies to business only resurged after the military takeover of the mid 1930s, when officers seized control of the state and established a corporatist economy under military control.

From the mid-1880s through to the 1920s, Japan was a free market economy with a small government focused on public goods provision - education, justice, and infrastructure. Comprehensive legal reforms laid down the rules, and businesses maximized shareholder value. The stock market grew rapidly, first augmenting, and then displacing, mines as a source of funds for rapidly diversifying business groups. Banks, linked to corporate governance after World War II (Kaplan and Minton, 1994), for the most part, played little direct role in financing industrialization role during these liberal decades.

In these decades, as in the earlier Meiji era, corruption, though undoubtedly present, was not prominent. Successive liberal governments kept paying senior civil servants very high salaries, giving them much to lose. The much criticized postwar practice of government officials' amakudari (descent from heaven) into sinecure jobs in private-sector firms was not yet commonplace. ${ }^{11}$ However, it also seems likely that the return to political rent seeking was lowered by governments' resistance to providing subsidies, and by the limited role the government assigned itself. There is, after all, little point in bribing government officials who lack the power to provide large subsidies or other valuable favors in return (Murphy et al. 1993)

Nonetheless, because these decades built upon the ruins of the previous state-led Big Push, they cannot be characterized as free of government subsidies. Private sector firms found much of value in those ruins. Most of the failed SOEs had imported advanced Western technology and management methods. The state had paid for these technology and expertise transfers, and of their actual implementation in Japan - often by highly-paid foreign engineers. Whenever an SOE sought additional technology and expertise, the state had again footed the

\footnotetext{
${ }^{11}$ High-level bureaucrats of the Meiji government were paid highly, scrutinized daily by political leaders of the powerful domains such as Satsuma and Choshu, and also faced serious national problems diplomatic, public finance, economic, military, and educational, to name but a few. These all required serious attention. At the same time, salaried upper-level managers of the emerging zaibatsu groups plausibly had incentives compatible with national goals (Morck and Nakamura, 2007, p.577, f.n.101). All this left little room for cozy practices such as the post-World War II amakudari (Aoki, 1992).
} 
bill. The SOEs were financial failures, but they littered the Japanese landscape with working models of foreign technology and business management that private investors could buy. In a sense, the losses the government absorbed - the cost of establishing and nurturing the SOEs minus the revenues from their privatization - can be thought of as state subsidies for the second zaibatsu-led industrialization. However, that this constituted a relatively efficient means of providing such subsidies is far from clear.

These decades were Japan's "high growth period". In the 1880s, Japan was poor and backwards. By 1920, it boasted an industrial economy on par with that of France, and had defeated the Russian Empire in one war and China in another, taking Korea, Manchuria, and Taiwan as colonies. This section describes the role of natural resources in this achievement

\subsection{The Rise of the Zaibatsu}

Putting this description in proper context requires a digression on the zaibatsu, a set of large family-controlled pyramidal business groups that rose to prominence in these decades, took charge of Japan's natural resource sector, and used earnings from that sector to build a modern industrial economy with remarkable alacrity. The predominance of the zaibatsu in this era of Japan's economic history is so overwhelming that their history is essentially Japan's history.

[Table 5 about here]

The three largest zaibatsu groups, Mitsui, Mitsubishi and Sumitomo continued expanding their market shares in Japan's important industries. Table 5 shows the shares (measured in total assets) of these three zaibatsu groups' companies among the top 100 companies in each of the industries listed. In the industries where these thee zaibatsu groups' shares are not high, the newer zaibatsu groups including Nissan, Furukawa and Kawasaki became dominant. These industries include chemicals including fertilizer and synthetic textiles. The zaibatsu group companies in Japan's key industries were dominant also in technological investment and had much influence on smaller unrelated companies in these industries.

Common to all of their histories is a relatively simple pattern. Each began as a tightly focused family business. Each quickly got into natural resources, if this was not the initial family 
business. ${ }^{12}$ Each used earnings from its natural resources firms to found, expand, and (if necessary) subsidize bevies of new firms in diverse sectors. As their needs for capital grew, and came to exceed their natural resources earnings, these firms took to issuing shares in the rapidly expanding stock markets. By the early $20^{\text {th }}$ century, each zaibatsu came to resemble the structure illustrated in Figure 3.

[Figure 3 about here]

Morck and Nakamura (2007) posit that large pyramidal business groups of this sort are private sector structures that can "simultaneously plan the industrialisation of several complementary industries" - the task that Rosenstein-Rodan (1943) assigned to government planners. Central control rests with the family by dint of the apex family firm in Figure 3 controlling every firm in the group - either by owning a control block in that firm or by owning a control block in a firm that, in turn, controls the firm in question either directly or through a chain of other firms. As the zaibatsu expanded, the largest of them achieved full set diversification - at least one firm in every important industry. This let each large zaibatsu approximate a miniature national economy: each member firm could find another member firm in whatever industry it needed to do business with. Because on family controlled all the firms in each zaibatsu, no member firm would gain by cheating or wielding market power against another. Morck and Nakamura argue that the zaibatsu took over where the Meiji state had failed, each vying to complete a Big Push within its internalized economy.

A key element of this coordination is tunneling (Johnson et al. 2000): shifting income between group member via trade in goods, services or investments at artificial transfer prices. Tunneling can siphon wealth upwards, concentrating it the apex firm letting the controlling family avoid sharing profits with lower tier firms' shareholders (Bebchuk et al. 2000; Bertrand et al. 2002; Claessens et al. 2000,2002). But tunneling can also transfer earnings from profitable mining firms to capitalize new firms in new sectors, finance coordinated growth across the group's existing firms, and subsidize unprofitable group firms deemed essential to the health of the group as a whole. Tunneling could let a well-governed pyramidal business group solve the coordination problems Rosenstein-Rodan (1943) assigns to the state. This is consistent with the

\footnotetext{
12 The only exception was the Sumitomo family, which started as a copper merchant.
} 
superior performance of group member firms in emerging economies (Khanna and. Rivkin. 2001) and the more general hypothesis that they facilitate development (Khanna and Fisman 2004).

Each major zaibatsu expanded by funneling earnings from its natural resources firms into broad expansion across multiple industries. However, the precise ways in which each did so differ. We therefore summarize the role of natural resources in each.

\subsection{The Importance of Natural Resources Firms in the Mitsui Zaibatsu}

The Mitsui, the country's oldest and wealthiest silk merchants, bought several SOEs in the mass privatization. Some, notably the Shinmachi and Tomioka silk textiles mills, related to their traditional business. But their most important ex-SEOs were mines, especially the Miike coal mines, for these financed much of the Mitsui zaibatsu's early expansion.

The Mitsui Bank, the family's first new firm outside the silk trade, was established in 1876 to provide a fire wall around its traditional silk business. First, the family cast out Takenosuke and Yonosuke Mitsui, each representing a major subclan, and they legally renounced their Mitsui birthrights. ${ }^{13}$ Takenosuke and Yonosuke owned Mitsui Bussan, a trading company, whose charter acknowledged control by Mitsui Bank, which had no assets but was controlled by the Mitsui family. This structure allowed the Mitsui to funnel earnings mining into various uncertain business ventures without exposing their core silk business to undue risk.

Mitsui Bussan, from the outset, was fueled by natural resources earnings: initially by commissions shipping coal to China for the Miike mining SOE and, after Mitsui bought this SOE outright in the mass privatization, by mining earnings. It served as a cash cow for the expanding business group for decades.

In the mass privatization, the family also bought several textiles SOEs, and used their foreign technology to modernize their existing silk business. The group now included Mitsui Bank; Mitsui Mining, which controlled its mines; Mitsui Bussan, which controlled its coal trade and the general merchant shipping businesses that grew from it; Mitsui Clothing Stores (later

\footnotetext{
${ }^{13}$ Their birth certificates were restored after an 1893 legal reform allowed limited liability for joint stock companies, obviating the need for a pretended division in the family.
} 
renamed Mitsukoshi); Mitsui Real Estate; and Mitsui Industry, which owned the family's venerable silk works alongside Shibaura Electric, whose expertise helped modernize the other firms. After a new German inspired commercial legal code came into force in $1893,{ }^{14}$ the Mitsui reorganized the zaibatsu: Mitsui Bussan, Mitsui Bank and Mitsui Mining became fully owned by the family. Mitsui Bank held equity control blocks in Oji Paper and Kanegafuchi Boseki (Kanebo) Textiles, with minority shares sold to public shareholders. Mitsui Mining earnings now began to flow into new ventures.

The Mitsui textiles business needed dyes, so Mitsui Chemicals became the first major diversification effort financed with Mitsui Mining's earnings. Mitsui Bussan needed a shipbuilding company in 1917 to support its growing shipping business. This, in turn, necessitated an iron and steel firm and an electrical equipment firm to provide inputs for shipbuilding. After artificial fibers appeared in the West, Mitsui Mining earnings helped capitalize Toyo Rayon to complement the silk business. Essentially all the group's diversification efforts were new subsidiaries of Mitsui Mining, Mitsui Bank or Mitsui Bussan, or new subsidiaries of their subsidiaries.

From the late $1890 \mathrm{~s}$ through the first decades of the $20^{\text {th }}$ century, the pyramid expanded, adding new firms in new industries as existing firms came to need them. By the early $20^{\text {th }}$ century, many had substantial public floats; and by the 1920 s most Mitsui firms were listed.

[Figure 4 about here]

Figure 4 shows that natural resources earnings remained important to the group

\footnotetext{
${ }^{14}$ In 1872, the government invited Prof. Gustave Émile Boissonade de Fontarabie of the Université de Paris to draw up a Western legal system. Boissonade drafted a criminal code in 1879, and began on a civil code. In 1878, the government invited Prof. Karl Friedrich Hermann Roesler of Universität Rostock to draft a commercial code and a constitution. Roesler finished an entirely Western draft commercial code leted in 1884. When this became public in 1890, the parliament deferred enactment to allow the insertion of Japanese elements. After a second deferral, a revised commercial code, company law, laws on the bills of exchange and promissory notes, and bankruptcy law followed in 1893 . These defined joint stock companies and Western business concepts. These legal reforms were critical to the 1894 Anglo-Japanese Treaty of Commerce and Navigation, and a spate of subsequent treaties with Western countries, to abolish extraterritoriality. The deferrals lapsed and the commercial code was fully enacted in 1898 and ratified in 1899. Roesler was conversant with the English, French, German Italian, and other legal systems and his original drafts blended features of many systems. However, Japanese legal experts working with him subsequently modified the draft constitution to reflect mainly German system (Takada, 2013).
} 
throughout these decades, and only slowly faded in importance relative to public equity issues. Coal and other mining earnings comprised half or more of all Mitsui companies' consolidated earnings from 1875 through 1913, falling to around 30\% during World War I and even lower in the 1920s. The Mitsui actively tunneled earnings between firms and into others as the group expanded. Mitsui Partnership recycled Mitsui Mining's earnings into subsidies for Wanishi Iron and Steel Works and Kamaishi Iron and Steel Works for many years, until retooling and expansion let them to achieve sufficient economies of scale to turn profits (Miyajima 2004). Even after the group came to rely primarily on public equity issues, retained earnings from mining operations left existing firms sufficient capital to retain effective control blocks in new and expanding group firms.

\subsection{The Importance of Natural Resources Firms in the Sumitomo Zaibatsu}

The Sumitomo family ran the Besshi copper mines for centuries under a Tokugawa mandate. During the SOE-led industrialization attempt, the Meiji reformers expropriated these mines; but quickly reversed course, returning them a month later. Nonetheless, the family's general manager, Saihei Hirose, never again trusted the reformers. Sumitomo bid for none of the SEOs offered for sale in the mass privatization program, and kept their distance from the government.

Nonetheless, he immediately set about thoroughly modernizing the Besshi operation, hiring Pumpelly and Blake students, as well as foreign-trained engineers and technicians, away from the SEOs. Sumitomo thus indirectly participated in the mass privatization by acquiring the SOE mines' finest talent.

Saihei Hirose also believed in focus, so Sumitomo remained an undiversified copper firm until his departure. The group's second firm, Sumitomo Bank, was thus not established until 1895. The bank grew quickly though, and overshadowed Mitsubishi Bank by the early 1900s.

The Sumitomo forestalled diversifying until clear bargains were on offer. Japan boomed during World War I, but entered a deep recession thereafter, especially after the Great Kantō Earthquake destroyed a substantial fraction of its modern infrastructure in 1923. Flush with copper mining revenues, Sumitomo Copper and Sumitomo Bank were well positioned to acquire fundamentally sound, but financially distressed firms in the post-earthquake downturn 
(Hatakeyama; 1988).

Like Mitsui and Mitsubishi, Sumitomo expanded first into complementary or vertically related lines of business, and then more widely. From copper mining, they entered bulk copper and copper wire production and iron and coal mining; and from the latter into iron and steel production. Complex business dealings required sophisticated financial services, hence the Sumitomo Trust Bank in 1926. Shipping and storing valuable metals and metal products required insurance, so the Sumitomo acquired first Hinode Life Insurance in 1925, which they rechristened Sumitomo Life Insurance, and then Fuso Marine Fire and Casualty Insurance in 1930, which they renamed Sumitomo Marine Fire and Casualty Insurance. To justify boosting the scale of their coal mining operations, the Sumitomo created Sumitomo Chemicals to produce ammonia/nitrogen fertilizer at new coal-based chemicals plants in 1928.

The Sumitomo sought no public equity until the pyramidal model was already well tested by the Mitsui. Their untiring cash cow, Besshi Copper Mines, continued yielding healthy earnings, but as the $20^{\text {th }}$ century unfolded, the Sumitomo needed even more capital. Their first listed firm, Sumitomo Fertilizer, went public in 1934 (Miyajima, 2004, pp.218-220). Thereafter, Sumitomo firms went public in rapid succession and the group stretched into a pyramidal structure like that of the Mitsui zaibatsu (Miyajima, 2004). Nonetheless, as Figure 5 shows, natural resource earnings remain a huge fraction of the overall group's earnings well into the new century.

Ultimately though, as Figure 6 shows, by 1928 the zaibatsu had achieved full set diversification, with operations in nearly every sector of the economy. At this point, Besshi contributed only $3 \%$ of the group's total earnings, and all three of its mining firms together contributed only $5 \%$.

[Figures 5 and 6 about here]

\subsection{The Importance of Natural Resources in the Mitsubishi Zaibatsu}

Another great pyramidal business group, with firms scattered across all major industries, the Mitsubishi zaibatsu formed around a shipping firm founded by an upstart entrepreneur, Yataro Iwasaki (1834-1885), in 1872. Iwasaki understood Western accounting, a rare skill at the time, and leveraged this into a genuine business edge, especially in dealings with foreigners. But, 
unlike the Mitsui and Sumitomo, he also invested heavily in connections with government officials. Though the prevailing Victorian laissez-faire economics precluded his gaining overt subsidies, Iwasaki managed to accrue regulatory favors and even a regulated monopoly.

Mitsubishi was a maritime shipping firm, and Iwasaki took pains to remind the Meiji reformers that he ran a "national champion" and to cooperate enthusiastically with their illfated SOE-led industrialization program. Thus, the government not only switched its business from Postal Steam Ship Co. to Mitsubishi, but bought all Postal's ships and simply gave them to Mitsubishi. From 1875 on, Mitsubishi's newly established Yubin Kisen Mitsubishi Kaisha shipping company received annual payments of $¥ 250,000$ for carrying government mail.

Most of this was a subsidy to protect Mitsubishi from competition. More subsidies may have come from Nagasaki Shipyard, an SOE that repaired and maintained Mitsubishi ships possibly at cut rates. Other shipping firms, foreign and Japanese, could not compete and, by the mid-1870s, most large ships in Japanese ports belonged to Mitsubishi. The early Meiji reformers saw domestic control of foreign trade as a key strategic objective, and deliberately subsidized Mitsubishi to lock in a Japanese monopoly.

Mitsubishi thus loyally accumulated wealth during the state-led Big Push of the 1870s, and then loyally stepped forth to buy SOEs in the subsequent mass privatization. Perhaps most importantly, Mitsubishi bought Japan's most prominent ex-SOE, the already privatized Takashima coal mines. The politician Shojiro Goto, who initially bought these from the government, but ran them poorly. Iwasaki, emphasizing the huge favor he was doing for the government in rescuing the unfortunate Goto, relieved him of the mines in 1881. Iwasaki was largely talked into buying Takashima mine by Keio Gijuku founder Yukichi Fukuzaw,a whom Iwasaki regarded highly. Fukuzawa saw substantial political capacity in Goto and wanted Goto to run for a political office. Mitsubishi's cash investment for the Takshima project was about 1.3 million yen after accounting for all its financial obligations including an unpaid balance of the original price due to the government. Mitsubishi's new accounting policy required an interest charge on the investment, with principal plus $10 \%$ interest payable to the group's apex firm (Oishi, 2005; Mori, 1973). Nevertheless, Takashima's Western mining technology and Mitsubishi's massive efforts to restructure its management let it pay off the debt in full by 
$1884 .^{15}$

Thereafter Takashima continued remitting a cash flow, often amounting to over $¥ 400,000$ (Oishi, 2005, p.20). Takashima Coal Mining continued producing for decades, and became the group's primary "cash cow". Takashima's cash flow to Mitsubishi Limited Partnership was the largest among all Mitsubishi companies during this period.

Mitsubishi's political connections had only limited benefits - the officials had little power to intervene in the economy - and might even have been counterproductive. Political rivals attacked Mitsubishi's politician friends for manipulating shipping and passenger fares to aid the zaibatsu; and the retirement of two of Mitsubishi's most important political connections, Toshimichi Okubo and Shigenobu Okuma, heralded yet more attacks, this time against the Mitsubishi patriarch Iwasaki for diverting government subsidies given to Mitsubishi's shipping monopoly into the zaibatsu's other businesses. Mining proved a more placid cash cow than the state-sanctioned shipping monopoly.

In 1882, the government forbade Mitsubishi from operating in any businesses other than shipping on pain of losing further subsidies, and approved Mitsui's new maritime shipping firm, Kyodo Unyu Kaisharun, run by military officers. The competition halved Mitsubishi's shipping revenues by 1883 . Appreciating the cost of disharmony in 1885 , Iwaskai agreed to merge the two shipping firms into Nippon Yusen Kaisha, renamed Nippon Yusen Kabushiki Kaisha (NYK). This let Mitsubishi remain in mining and other sectors.

The maritime shipping firm needed a reliable source of coal; and Mitsubishi could now export Takashima coal directly to China. Imposing double entry bookkeeping, ${ }^{16}$ shedding excess staff, and firing shirkers, Iwasaki soon made the mines a profit center. To leverage the technological and labor management expertise acquired at Takashima, Mitsubishi acquired over twenty more coal mines from 1884 through 1911. Of these, eleven became large-scale "cash cows" that kept funding Mitsubishi expansion as Takashima's relative importance waned. Thus, the Takashima mine played much the same role the Miike Coal Mine and Besshi Copper

\footnotetext{
${ }^{15}$ For details about the purchase of and the subsequent management issues at Takashima Mine, see Kobayashi (2003) and Oishi (2005).

${ }^{16}$ Mitsubishi modernized their accounting by introducing double entry book keeping to Japan, as promoted by Fukuzawa (1873) who brought the then standard U.S. textbook, Bryant and Stratton (1871), to Japan. See also Hitotsubashi (2003) and Shimme (1937).
} 
Mine played in the Mitsui and Sumitomo zaibatsu, respectively.

In 1887, Mitsubishi bought another SOE, the money-losing Nagasaki Shipyards, which it had operated for the government since 1884. Mitsubishi next took over the country's largest ship maintenance, shipbuilding and iron production facilities in Yokohama.(Kobayashi, 1977). Iwasaki expanded and modernized the Nagasaki Shipyards, and aggressively hired graduates from Japan's new engineering universities and others with modern training. By 1899, the thoroughly rebuilt Nagasaki facility was building state-of-the-art steel ships.

From 1891, group was organized as single conglomerate, a unitary firm with divisions corresponding to each operating business, controlled by Mitsubishi Limited Partnership, the Iwasaki family firm. By the late 1880 s, all interdivisional transactions passed through the $119^{\text {th }}$ National Bank. Its double entry bookkeeping shows more directly than is possible in the other zaibatsu how natural resources earnings financed expansion into new sectors. Each division's after-depreciation earnings redounded to the partnership, and after 1896 a 2\% per day interest change on excess working capital insured timely compliance. In this way, earnings from mines (and the subsidized maritime shipping business) were reallocated to capitalize new lines of business, to expand existing lines of business with growth opportunities, and to subsidize lines of business operating losing money but deemed essential to the conglomerate as a whole.

Unlike the apex firms of the other zaibatsu, the Mitsubishi partnership "outsourced" the capitalization of new firms, empowering Iwasaki relatives to use their income from the partnership to set up new businesses on their own. This practice was especially useful when the government's condition for continued subsidies to Mitsubishi's shipping was that it not enter other specific lines of business. Iwasaki relatives established Meiji Life Insurance in 1881. Other Mitsubishi companies appeared in glass making (Asahi Glass, 1907), brewing (Kirin, 1907) and other industries. These initially had no formal links to the Mitsubishi Partnership, but apparently were actually subject to it and dependent on it for capital. Thus, the Mitsubishi partnership ruled a constellation of lesser firms in addition to the vast Mitsubishi conglomerate.

Mitsubishi partnership ran an experiment from 1909 through 1913 that illuminates its economic coordination function. Although the conglomerate relied on division managers for information about investment opportunities, the actual decisions were made centrally. In 1909, 
the minerals mining division was allowed to retain and invest $90 \%$ of its earnings; and in 1911 the other mining, shipbuilding, and sales divisions gained the same privilege and the real estate division was allowed to retain and invest $96 \%$ of its earnings. The division managers, especially in mining and shipbuilding, opted to pile up retained earnings and rarely funded any new investment.

In 1912, the family terminated this test trial, and in 1913 reasserted its role as the nerve center for all divisions, save shipbuilding. Thenceforth, divisions provided the head office detailed pro forma accounting statements, and it would then determine retention levels, borrowing, and capital budgets for each division. The head office planned all growth opportunities that affected more than one division, as well as all entries into new industries. This nicely highlights the head office's cross-industry central planning role. The experiment also highlights how fully Mitsubishi depended on natural resources earnings to finance growth in other sectors.

By this time, the Mitsui had demonstrated the efficacy of the pyramidal structure in Figure 3 for raising vast amounts of equity capital from public investors while keeping tight family control over all decision-making. Mitsubishi, increasingly finding retained earnings from mining insufficient to match the capital expansion programs of other zaibatsu, followed suit. Mitsubishi Mining was reorganized as a separate corporation, and listed in 1920. Subsequently, one by one, the other major Mitsubishi went public as controlled listed subsidiaries, and many then issued yet more shares. ${ }^{17}$

Some of these secondary issues were leverage-reducing recapitalizations, which let the subsidiaries pay off their debts to the Mitsubishi Bank. By the 1920s, most Mitsubishi Bank loans were to individuals and businesses unaffiliated with the group, and by 1928 most Mitsubishi firms were largely free of bank debt, though some had outstanding bonds. This strategy helped the group weather coming financial crises - the Great Kantō Earthquake of 1923 and the Great Depression of the 1930s.

\footnotetext{
${ }^{17}$ Tamaki (1976, pp .84-86) notes that, although lower tiers of the Mitsui zaibatsu were often reorganized, Mitsui Mining was always a direct subsidiary of the family partnership. Fruin (1992, pp.100-102) describes how the Mitsubishi pyramid was reorganized several times between 1916 and 1926 , and argues that this reflected evolving strategic considerations such as economies of scope and scale.
} 
Ongoing equity issues diluted the Mitsubishi Limited Partnership's equity stakes in its listed subsidiaries from an average of $85.5 \%$ in 1921 to only $69 \%$ by 1928 . To keep the family's control blocks above 50\%, the group's first tier firms limited their share issues, and firms in lower tiers began capitalizing their own controlled subsidiaries in yet lower tiers with initial public offerings. Successive tiers of subsidiaries plausibly exacerbate public shareholders' concerns about tunneling wealth upwards from lower tier firms owned in large part by public shareholders to the family firm at the pyramid's apex; but this strategy nonetheless preserved family control as the pyramid grew. Possibly, the family's public descriptions of how the apex firm collected and then rationally reallocated retained earnings were designed to counter such concerns. In any event, by 1928 , the Mitsubishi zaibatsu was a multi-tiered pyramidal structure similar to the Mitsui and Sumitomo zaibatsu.

Table 6 presents a snapshot of the Mitsubishi zaibatsu apex firm's income from group firms in different industries and the capital spending in each sector, as of 1935, near the end of Japan's laissez-faire era. Mining remained the group's major "cash cow", still generating over a third of the head office's income. The role of the apex firm in coordinating capital spending is evident in the discord between the capital spending and income figures. For example, Mitsubishi Partnership's retained earnings from mining not only fully capitalized the new Mitsubishi Iron and Steel in 1917, but also financed all its capital spending for years thereafter (Mishima 1981, p.143; Miyajima 2004, p.180). In its first years of its operation, Mitsubishi Iron and Steel lost money because its scale of operation was too small to cover fixed costs. Mitsubishi Partnership absorbed these losses when the steelmaker wrote down its capital by five million yen in 1924 , and injected further subsidies of $¥ 12.5$ million 1924 and $¥ 11$ million yen in 1928. This came from Mitsubishi Partnership income from its mining and, shipbuilding firms. The steelmaker's efficiency improved through the 1920 s as its scale of operation expanded (Okazaki 1933; Miyajima 2004, pp.180-182).

[Table 6 about here]

\subsection{The Importance of Natural Resources Firms in the Nissan Zaibatsu}

Japan's fourth great zaibatsu is, in some ways, the most interesting. Sumitomo began with a 
family natural resources firm; and Mitsui and Mitsubishi used earnings from a family silk business and a state-protected shipping monopoly, respectively, to acquire natural resources cash cows. Nissan, in contrast, used public equity to acquire natural resources cash cows. Nissan was a latecomer, so equity markets and the pyramidal group model were already welltested. Besides, Nissan's impecunious founders - Husanosuke Kuhara and his brother-in-law, Yoshisuke Aikawa - had neither family money nor government connections, so public equity was their only option.

During World War I, Japanese mines worked at full capacity to supply the Allies, and the economy boomed. Taking advantage of public investors' appetite for resource stocks, Kuhara floated a $¥ 2.4$ million IPO to capitalize a new firm - Kuhara Mining. He then embarked on a spate of takeovers, and by 1919, Kuhara Mining controlled 50\% of the country's silver mining, $40 \%$ of its gold mining, and $30 \%$ of its copper mining; as well as a trading company, Kuhara Trading.

After the war, metals demand sagged and Kuhara Trading, unable to balance its books, threatened to pull down Kuhara Mining. Kuhara retired and Aikawa, a U.S. trained engineer with up-to-date training in iron casting, took charge. Aikawa had navigated his own small firm, Tobata Cast Iron, through the postwar turbulence. Putting his own savings into Kuhara Mining, Aikawa jawboned relatives, managers, and outsiders for more capital and ultimately raised over $¥ 25$ million to keep Kuhara Mining afloat; and became its president.

But the firm's long-term financial health remained uncertain. To raise more capital in 1928, he listed a new holding company, Nippon Sangyo, or Nissan. Nissan used its IPO revenue to capitalize a subsidiary, Nippon Mining, which Aikawa then merged with Kuhara Mining. This reverse takeover left Nippon Mining listed, but controlled by Nissan, which was widely held. Nissan could then capitalize more listed subsidiaries, and these could capitalize yet more listed subsidiaries.

Aikawa rapidly built a large, diversified pyramidal group beneath the widely held apex firm, Nissan. The pyramid grew by acquiring control blocks in existing companies, a far faster growth trajectory than building new facilities from scratch would have allowed (Udagawa, 1976). Nissan soon approached full set diversification, with major new subsidiaries in heavy 
industry, chemicals, electric power, and other diverse sectors; and these with their own listed subsidiaries, which listed their own subsidiaries in turn, all spread across different sectors. Content with equity financing and averse to debt because of the near bankruptcy of Kuhara Mining, Aikawa saw no need for Nissan to have a bank, and kept the group's member firms from running up leverage.

This was a new model in Japan. The Mitsui, Mitsubishi and Sumitomo pyramidal groups tapped public equity extensively, but always via controlled subsidiaries subject to an unlisted family-controlled apex firms (Morikawa 1980, 1992; Morck and Nakamura 2007). The new group's apex firm, Nissan, was not only listed, but widely held. This exposes the coordination role of the apex firm from another perspective, which Aikawa spells out in Figure 7, taken from his autobiography. This diagram represents Nissan and its directly owned subsidiaries as a plumbing system, through which money flows. Because the apex firm, Nissan, was widely held, Aikawa ran the entire structure to maximize the money level in the 'public holding company tub' so it could pay a steadily growing dividend. Money levels in Nissan's many operating subsidiaries, the smaller capital tanks at the top of the diagram, are equalized by drainage into a common pipeline extending to Nissan and their public shareholders. The prominent bidirectional valves on the pipe linking their primary inflow and outflow pipes is adjustable, as is the flow directly out of the top of the holding company tub, letting Aikawa raise or lower the overall water levels in all the subsidiaries and prevent profitable ones from accumulating earnings and less profitable ones from draining empty. A parallel system of debt financing pipes tapping water from a financial institutions tub completes the system. The 'public capital tub' at the bottom of the diagram acts as a reservoir to stabilize the money levels in the group's securities issues and treasury securities sales tubs.

Mining companies were important earnings generators for the Nissan zaibatsu plumbing system. In 1928, six years before this diagram Aikawa presented this diagram to Tokyo bankers, he established Nippon Sangyo (Nissan) as a publicly traded holding company whose main operating subsidiaries were Nippon Mining (now JX Nippon Mining and Metals) and Hitachi Limited, which also had mining operations (Sugiyama ,2012). Both were among the subsidiaries $(E 1, E 2$...) in the diagram. Subsequently, Hitachi Mining, among the most productive copper 
mines of the era, helped Aikawa capitalize, expand and subsidize other Nissan zaibatsu firms.

[Figure 7 about here]

Aikawa (1934, p. 13) specifically justifies using overall profits to subsidize losses in firms needed by other firms, and investing in "a few new business lines" that would lose money, but were nonetheless likely to augment Nissan's long run financial health and "important to the nation". These ventures included an auto manufacturing firm, subsequently named Nissan Motor, an Antarctic whaling business, and a broadcasting company Udagawa (1976, p.134, p.142).) As Nissan expanded, Aikawa structured intercorporate voting blocks and crossholdings so that Nissan controlled every firm in the group. This prevented the shareholders of earnings donor firms from objecting to his draining their firms' money into his system of pipes and values when this boosted Nissan's own share price.

Nissan's shares remained relatively buoyant through the Great Depression (Udagawa, 1976, p.122); and its repeated seasoned equity issues to finance opportunistic $M \& A$ in the bear market were well-subscribed. Aikawa's overall strategy was to buy promising firms, grow them as fully owned subsidiaries, and then relist them as controlled subsidiaries (bunshin kaisha). The Nissan pyramid expanded rapidly, as did the widely held apex company. The apex firm's shareholder base rose from 20,000 in 1934 to 51,804 in May 1937, and 98\% owned fewer than 500 shares each. Only 33 shareholders owned more than 10,000 shares, and the Aikawa family's combined stake totaled only $5.2 \%$ by 1937 (Udagawa, 1976).

Aikawa's (1934) autobiography stresses his duty to the shareholders of the widely held apex firm, NIssan. This meant that individual Nissan companies were explicitly and unapologetically managed to maximize the shareholder value of the apex firm. The families owning the unlisted Mitsui, Mitsubishi, and Sumitomo apex firms almost surely ran their business groups to maximize family wealth, and this plausibly roughly approximated maximizing the values of their apex firms. But Aikawa both spelled it out and declared explicitly that this mandated broad diversification of the group as a whole, so that Nissan firms could depend on other Nissan firms, rather than on arm's length transactions with unrelated firms or, perhaps even worse, with member firms of other zaibatsu. By 1937, the group included Nippon Mining, Hitachi, Ltd., Hitachi Power, Nissan Motor and numerous other large manufacturers and utilities. 


\subsection{How Lacking Natural Resources Firms Hurt the Suzuki Zaibatsu}

The Mitsui, Sumitomo, Mitsubishi, and Nissan zaibatsu all rose on natural resource earnings. A fifth great zaibatsu, Suzuki, shared their pyramidal structure and full set diversification, but differed starkly in lacking a natural resources cash cow. Instead, the Suzuki group's apex firm, run by general manager Naokichi Kaneko, ${ }^{18}$ used its financial affiliate, Taiwan Bank, as its cash cow. Because the bank was financially positioned far away from the apex firm, Kaneko had essentially no interest in the bank's share value. The bank took in deposits and lent to other Suzuki group firms to bankroll their industrial investment. In this sense, it played the same role that mining companies played in the other zaibatsu: capitalizing new firms and financing the expansion of existing firms as Kaneko planned and coordinated the construction of a fifth "centrally planned economy within a free market economy" that came close to rivalling those of the Mitsui, Mitsubishi, Nissan and Sumitomo zaibatsu.

However, using subsidized bank loans as a primary tunneling mechanism left Suzuki firms highly leveraged, while most firms in the other four zaibatsu were relatively or even completely debt-free. This also left Taiwan Bank's loan portfolio highly concentrated in Suzuki firms. In contrast, the Mitsui Bank, Mitsubishi Bank, and Sumitomo Bank all took in deposits and lent to unrelated individuals and firms. Because the Taiwan Bank's loan portfolio was still diversified across firms in many industries, the risk in this lending policy was not immediately apparent. After the risk became palpable, banks that lent primarily to other firms in their zaibatsu came to be called organ banks. While Taiwan bank was not the only organ bank, it was the largest and its collapse was the most precipitous.

The Suzuki group began as a sugar cane refinery in Taiwan, a Japanese colony since the 1895 Sino-Japanese War. Its first affiliate was a shipping company to transport sugar to Japan,

\footnotetext{
${ }^{18}$ The Suzuki zaibatsu grew out of Iwajiro Suzuki's Kobe-based firm, Suzuki Shoten, founded in 1874 This became one of the eight main trading firms in Kobe within a decade. When Iwajiro Suzuki died in 1894, his widow, Yone Suzuki, delegated power to the general manager, Naokichi Kaneko, and another manager. The Suzuki family retained ownership of Suzuki Shoten. Suzuki Shoten established sugar and camphor trading operations and rapidly expanded into other commodities and services. Their trading businesses often involved third countries only, and not Japan. Suzuki Shoten revenues reached 1.6 billion yen in 1919/1920, about a tenth of Japan's GDP.
} 
and more affiliates were cobbled on rapidly. By the Great War, the Suzuki zaibatsu's foreign trade exceeded that of Mitsui Bussan; and after the war, the group aggressively capitalized new firms in industry after industries. By 1923, the Suzuki group was roughly as large and diversified as the Mitsui or Mitsubishi groups. On March 14, 1923, Kaneko reorganized the group under a new apex firm, Suzuki General Partnership that directly or indirectly controlled seventy-eight different listed firms, each financed with a mixture of public equity and loans from the Taiwan Bank. Of these, ten were in food, twenty four in chemicals, four in textiles, two in tobacco, five in mining, five in iron and steel, three in electric machinery, three in electric power, three in railways, two in shipping, two in fishing, two in real estate and warehousing, three in development, two in the banking and trust business, and four in insurance, three in commerce. The Suzuki zaibatsu's pyramidal structure was completed at this time, with all its subsidiary firms listed, and relying on various mixes of debt from Taiwan Bank and public equity.

Kaneko did construct alternative potential cash cows by importing technology. For example, the Suzuki zaibatsu established an "artificial silk" business by reverse engineering (or possibly merely copying) Western technology for producing rayon. ${ }^{19}$ The group's rayon maker (now Teijin), expanded rapidly, and by 1937, Japan was producing as much rayon as the United Kingdom. Other group firms developed the genuinely new viscose method for producing artificial silk. However, artificial silk never meaningfully supplanted Taiwan Bank loans as a source of capital for other Suzuki firms - perhaps because Kaneko owned a major equity block in the rayon firm, but had scant direct financial interest in Taiwan Bank.

The group's demise began with the 1923 Great Kantō Earthquake, centered on Tokyo and Yokohama. The quake leveled much of Japan's industrial infrastructure and badly disrupted trade credit and financing arrangements. The Taiwan Bank, invested almost fully in Suzuki firms' now badly damaged property, plant and equipment, was crippled. The Bank of Japan absorbed its earthquake-related losses non-performing loan losses, many of which were Suzuki's firms' debts. The earthquake-damaged economy collapsed into the 1927 Showa financial depression, effectively cutting Japan out of the Roaring Twenties. Japan nonetheless participated fully in the Great Depression, which spilled over from the United States and left the Taiwan Bank

\footnotetext{
${ }^{19}$ See Miyajima $(2004,230)$ \& Teijin's website www.teijin.co.jp/english/eco/index.html
} 
unable to renew loans to Suzuki firms, leaving them all without access to working capital. The firms of the Suzuki zaibatsu declared bankruptcy on April 5, $1927 .^{20}$

The Mitsui, Sumitomo, Mitsubishi and Nissan groups survived the crisis despite also absorbing huge earthquake damage. Their mining firms' assets-in-the-ground collateralized emergency loans, their mining earnings provided emergency cash, and their group banks were unthreatened, having lent mainly to unrelated borrowers throughout Japan. Perhaps, had Kaneko invested in political connections, he might have procured a bail out, but he overtly scorned political rent-seeking. However such vast losses and so laissez-faire an ethos may well have precluded a bailout in any event. An alternative history might be that, had the group a natural resources cash cow, it would have survived.

\section{Japanese Exceptionalism}

Japan grew rich, and by the 1920s was pulling alongside Italy and other late industrializers in Western Europe, though its per capita GDP remained somewhat lower than the richest developed economies of the era (Figure 8). This made Japan the era's miracle economy: the first non-Western country to escape Malthusian equilibrium and Asia's first indigenous industrialized economy. These accolades are entirely legitimate. By the 1920s, Japan's industrial structure was assuming the form typical of advanced Western economies. Figure 9 shows the steady broadening diversification of the economy through the early $20^{\text {th }}$ century. By the 1920 s, Japan's industrial composition came to resemble Canada's, another late $19^{\text {th }}$ century industrial debutant; with both depending more on agriculture, forestry, and the like than earlier industrializers (Morck and Nakamura 2007).

[Figures $9 \& 10$ about here]

Japan's natural resources-based industrialized achieved its goal: rapid industrialization sufficient to produce weapons necessary to defeat (for a while) foreigners. Japan defeated China, in 1895, seized Taiwan as a colony, and took de facto control of Korea, annexed as a colony in 1910. In 1900, Japan joined the allied occupation of Beijing to free international

\footnotetext{
${ }^{20}$ After Suzuki's collapse, its general trading division was reorganized as Nissho Company (now Sojitsu). Several other ex-Suzuki firms, including Teijin and Kobe Steel, were also reorganized and continue as independent companies. Many other ex-Suzuki companies were absorbed by the Mitsui zaibatsu.
} 
diplomatic personnel being held captive. In 1905, Japan defeated Russia - the first instance of an Asian country defeating a European empire in modern times -and seized the southern half of Sakhalin Island, off the coast of Siberia. The victory also left Japan in de facto control of southern Manchuria, previously a Russian-controlled region of China.

By the early 1930s, Japan's democracy was collapsing under a wave of selective assassinations of civilian politicians (by the military), which left top military officials the only candidates for political leadership. In 1931, Japan formally annexed all of Manchuria. A few years later, Japan had conquered much of Asia, defeating the British in Burma, Hong Kong, Malaysia, and Singapore; chasing the Dutch from Indonesia and the French from Vietnam. Japanese planes were soon bombing Australia and Hawaii.

The Meiji program of learning foreign ways to defeat foreigners was resoundingly successful. The fact that Japanese living standards were still short of Italy's was more a sign of the country's priorities than of laggard development in comparison to Italy. Why did Japan's natural resources-based economy manage to industrialize so rapidly, while so many other natural resource-based economies, then and now, could not? How did Japan defeat the natural resources curse? Several features distinguish Japan, and are plausibly important.

First, Japan's traditional feudal elite, its warlords and samurai, were utterly discredited and had negligible influence after the 1870s. Reischauer (1988, pp.81-83) explains

"With the disappearance of the domains, the samurai lost their position as a hereditary bureaucratic class, and in 1873 universal military conscription was substituted for the old class basis for military service. In 1876 the samurai were even prohibited from wearing their swords, their badge of distinction. Samurai stipends were also drastically reduced and by 1876 were entirely commuted into relatively small lump-sum payments of cash or government bonds. Thus the samurai in a brief nine-year period were deprived of all their privileges, and Japan was started on a great change that was to transform its society in a mere generation or two from one in which status was determined primarily by heredity to one in which it depended largely upon the education and achievements of the individual." 
Acemoglu, Johnson, and Robinson (2001, 2002, 2005) argue that traditional elites in nonWestern societies are typically predisposed to extractive economic activities, such as running large estates or mines; and favor policies that favor these operations and which, perhaps inadvertently, limit the rise of a middle class. Japan's Big Push perhaps worked because its traditional elite were uniquely marginalized. This left a blank slate on which the reformers could design elections, legal reforms, and constitutional government, as well as universal education and a free press.

Second, Japan's might was the achievement of a democracy, of an economy grown modern under political pluralism, the rule of law, and a generally competent series of governments no less democratic than in most Western countries at the time. Political competition reflected the reformers divisions into regionally based factions. Each faction mistrusted the others, and none was strong enough to dominate parliament or policy-making. Each faction's backers both inside and outside government closely monitored the other factions' doings, and enthusiastically tipped the newspapers about any officials' decision that appeared illegal, or even just unusual. Consequently, no faction dared engage in overtly corrupt dealings lest it be exposed. This meant that politicians' careers depended on their competent management of the government and on broad based economic growth. Because government officials were well paid (see Figure 10), they had much to lose if their careers ended in corruption scandals. Indeed, overt ties to big business could be positively dangerous: for example, Toshimichi Okubo, assassinated in 1878, and Shigenobu Okuma, forced out in 1881, were both widely perceived as too close to the Mitsubishi zaibatsu, whose shipping firm was then competing ferociously with Mitsui's. Japan's democracy lasted until just before World War II, when its admirals and generals seized power by exploiting a fatal flaw in the constitution that left the top military leaders above the law and free to take over the government by assassinating party politicians.

[Figure 10 about here]

Third, Japan's rapid industrialization occurred during a period of small government and unfettered market forces. The state gave an initial push in establishing the SOEs and endowing them with foreign technology. But it then withdrew. The mass privatization restored public 
finances, but left politicians and voters leery of state intervention. Moreover, Japan's abrupt opening to the outside world under Commander Perry's guns was formalized with a sequence of so-called unequal treaties. These made Japan an open economy in a time of global free trade and capital flow. Economic openness is linked to more sustained (Rajan and Zingales 2003; Stulz and Williamson 2003) and faster capital investment flows (Henry 2000ab, 2003; Choe and Stulz 1999). The unequal treaties also empowered foreign courts to apply foreign law to disputes in treaty concession enclaves, thus demonstrating a spectrum of foreign legal systems in action. La Porta et al. (1997) link legal system structure to financial development, suggesting another possible hidden boon in the unequal treaties.

This leads into a fourth reason: political corruption was not severe during these decades, despite vast economic power of the great zaibatsu, and the vast political power such business empires often give their controlling families (Rajan and Zingales 2003; Morck and Yeung 2004, Morck, Yeung, and Wolfenzon 2005). ${ }^{21}$ Japan's SOE-induced financial crisis so tainted big government that only laissez faire policies remained on the table for decades. Laissez-faire economic policies make influencing government officials a relatively low-return investment because the officials have little power over the economy. ${ }^{22}$ Rather, the highest returns on offer were developing new technology and other productivity enhancing projects, so that is where the zaibatsu put their natural resources earnings. Moreover, because those earnings

\footnotetext{
${ }^{21}$ The era's biggest corruption allegations surrounded the 1874 test privatization of Takashima Coal Mine, then the only mine with Western technology for vertical shafts. The politician Shojiro Goto bought the mine for $¥ 550,000$, borrowed from the British trading company Jardine, Mathewson. The government had nationalized the mine in 1874 , paying $¥ 390,000$ to its original owners, Saga-han (Saga domain) and Thomas Blake Glover, a Scottish trader. Its net book value was estimated at $¥ 393,848$ in 1885 , providing the government a book profit of $¥ 150,000$. Goto could not run the mine profitably, and resold it for $¥ 600,000$ (just enough to clear his debts) to Yataro Iwasaki, the as-yet unknown who would build the Mitsubishi zaibatsu. Iwasaki too failed to boost the mine's productivity immediately, largely because of major ongoing labor disputes (Kobayashi, 1977, 2003; Mori, 1973). As noted in 4.4, there was no evidence of any immediate gain for Iwasaki, who had to absorb not only the payment to Goto but also the original price Goto promised to pay to the Meiji government.

${ }^{22}$ The fraction of the annual government budget spent on industrial subsidies never exceeded $2 \%$ between 1890 and 1942. Which industries got subsidies changed over time, as did tariffs. For example, import duties on foreign-made ships rose in 1911 and several competing shipbuilding firms received subsidies during World War I, but the market share of foreign (British)-build ship purchases hovered at roughly $37 \%$ nonetheless. This, together with domestic competition between Mitsubishi and Kawasaki shipbuilding operations, arguably greatly limited their scope for rent seeking (Miyajima, 2004, p. 35).
} 
were ample, and because stock markets were soon booming, they could manage without subsidies (as long as no-one else got them). Also, the different zaibatsu supported different political parties; and while this left each party tied to a zaibatsu, competition between both the parties and zaibatsu was intense. This competition likely limited corruption because wrongdoings by one zaibatsu family were apt to be disclosed by another, or its supporters, to the newspapers.

Fifth, the zaibatsu business groups were not obviously poorly governed at the time. Pyramidal business groups are associated with a host of governance problems stemming from controlling shareholder's scant direct financial interest in member firms low in the structure (Bebchuk et al. 2000). Records attest to the Mitsui carefully positioning each firm in the pyramid, and carefully determining what stakes each should hold in its subsidiaries, putting more opaque firms, in which public shareholder trust is more violable, nearer the apex, where the family's incentive to self-deal is less. Second, the zaibatsu did not obviously collude to gain market power. Rather, each group seems to have been in meaningful competition with every other group.

This means that the wealth of the controlling family (or the value of shares in the apex firm, in the case of the Nissan zaibatsu) was maximized by efficiently allocating resources within the business group as a whole. Individual member firms in each group might not have been run to maximize its shareholder value (for example, Mitsubishi Iron long operated at an inefficient scale), but each group as a whole had to be competitive with the other groups (Mitsubishi had to have an iron works) or it would lose business to other groups. ${ }^{23}$ That managers' pay was not generally linked to the performance of the individual firms they run is actually consistent with

\footnotetext{
${ }^{23}$ Mitsui partnership founded an iron and steel business about the same time as Mitsubishi did. Mitsui's Hokkaido Coal Mining and Shipping had established Japan Steel Works, a joint venture with Britain's Vickers Sons and Maxim, Ltd.to produce munitions and steel products in 1907. Using this expertise, Mitsui established Wanishi Iron \& Steel in 1909 (renamed Hokkaido Iron and Steel in 1917, later renamed Fuji Steel, then Nippon Steel) in Muroran, a Hokkaido port Hokkaido Coal Mining developed for shipping coal out and bringing in raw materials. When Hokkaido Iron \& Steel was set up, it was $25 \%$ owned by the apex firm, Mitsui Partnership, $50 \%$ owned by Hokkaido Coal, and $25 \%$ owned by Mitsui Mining, the latter two being direct subsidiaries of Mitsu partnership. All Hokkaido Iron \& Steel's initial capital thus came from internal funds. Also paralleling Mitsubishi Iron's history, Wanishi Iron \& Steel and Mitsui Mining’s Kamaishi Iron \& Steel (acquired in 1924) received a $¥ 9.7$ million yen capital injection from other Mitsui firms (Okazaki, 1933, pp. 131-134; Miyajima, 2004, p. 182).
} 
good business group governance (Morck 2012). For example, a group member firm with monopoly power, say, over another might maximize its shareholder value by exploiting that power to the fullest extent possible, but this risk rendering resource allocation across the overall group inefficient. ${ }^{24}$ In contrast, pay-for-performance for people managing the business group as a whole could be extreme, as when Mitsui's managing director Takuma Dan, an MIT engineering graduate, was assassinated in 1932 for overseeing Mitsui's massive bet on the U.S. dollar.

Finally, each major zaibatsu rapidly became so broadly diversified that it constituted a virtually complete image of a national economy. Morck and Nakamura (2007) argue that competition between these economies-within-an economy kept resource allocation efficient within each zaibatsu, allowing the head office of each to centrally plan and coordinate the group's expansion, much as a central planner is envisioned doing in a state-led Big Push development program (Rosenstein-Rodan 1943; Murphy, Shleifer and Vishny 1989) but in general cannot do because of massive and inevitable government failure problems (Easterly 2006).

\section{Conclusions}

Japan was a major natural resource economy in the late 19th and early 20th centuries, the decades in which it industrialized rapidly and successfully. The country's resource wealth was largely exhausted as it industrialized, so Japan is correctly classified as a resource-poor economy today.

The Japanese government's first attempt to industrialize was via constellation of SOEs, one in each major industry, all to be financed by revenues from nationalized mines. This effort failed because the SOEs' soft budget constraints drained the government of funds and

\footnotetext{
${ }^{24}$ Companies closer to the apex firm related pay more to performance. For example, Mitsui Bussan and Mitsui Bank, both near the top of the Mitsui pyramid, paid managers and employees bonuses equal to a fraction of profits. However, miners at Mitsui Mining, the group's cash cow, were excluded. After 1893 when Japan's commercial code was set up, Mitsui's bonus policy changed: each firm passed a tenth of its earnings to a central Mitsui bonus pool, which was then divided across all Mitsui companies and thus not directly tied to individual firms' performance. After Mitsui Bank went public in 1919, this system ended and bonuses were set at the firm level. For further detail, see Kasuya (2006).
} 
precipitated a major financial crisis. Victorian liberals took charge and organized a mass privatization to restore government finances, and then implemented laissez-faire economic policies.

The privatized SOEs ended up as member firms in zaibatsu business groups controlled by various old merchant families, notably the Mitsui and Furukawa, or new entrepreneurs, notably Yataro Iwasaki and Yoshisuke Aikawa, the founders of the Mitsubishi and Nissan zaibatsu, respectively. Each zaibatsu began on a small scale, but rapidly expanded into almost every industry. In each of these zaibatsu, except Suzuki, natural resource member firms' earnings financed the capitalization of new firms, the growth of existing firms, and the overall expansion and diversification of the group. As the groups expanded beyond the capacity of their natural resource member firms' earnings, each switched to raising equity on the nation's rapidly growing stock exchanges - except that the Nissan and Suzuki groups used public equity from their beginnings.

Japan industrialized rapidly as these business groups grew, and by the 1920s was pulling alongside parts of Europe in living standards and coming to resemble industrialized economies in the sectorial makeup of its economy. This successful industrialization was largely led by the zaibatsu, and occurred under comprehensively reformed political, legal, and economic institutions, democratic government, lasses-faire economics, reasonably corruption-free government, and defensible corporate governance - or more accurately, business group governance. The zaibatsu groups competed with each other across industries while each zaibatsu pursued a big push of its own. That an ultimately favorable confluence of historical events dislodged and disgraced the pre-existing extractive elite is also likely important. Japan's economic history shows that natural resources can successfully finance the rapid industrialization of a non-Western economy.

Japan's depiction as a natural-resource-poor development success story may reflect the confounding of its 1880 s to 1920 s initial industrialization with its 1950 s to 1980 s postwar reconstruction The latter was indeed accomplished without significant natural resource 
earnings, for most mines were by then exhausted or nearly so. ${ }^{25}$ However, the initial industrialization of a low-income and the reconstruction of a war-damaged high-income economy are vastly different tasks, quite likely resonant to vastly different institutions.

\section{References}

Acemoglu, Daron, Simon Johnson, James A. Robinson. Source: The American Economic Review, Vol. 91, No. 5 (Dec., 2001), pp. 1369-1401.

Acemoglu, Daron, Simon Johnson \& James Robinson. 2001. The Colonial Origins of Comparative Development: An Empirical Investigation. American Economic Review 91(5) 1369-1401

Acemoglu, Daron, Simon Johnson \& James Robinson. 2002. Reversal of Fortune: Geography \& Institutions In The Making Of The Modern World Income Distribution. Quarterly Journal of Economics 117(4) 1231-1294.

Acemoglu, Daron, Simon Johnson \& James Robinson. 2005. The Rise of Europe: Atlantic Trade, Institutional Change \& Economic Growth. American Economic Review 95(3) 546-579.

Aikawa,Y. 1934. New Capitalism \& Holding Companies. Tokyo Bankers Association.

Akimoto, Hiroshi. 2004. Japanese Zaibatsu. Economia 55, May 2004, 1-16.

Alichi, Ali \& Rabah Arezki. 2012. An alternative explanation for the resource curse: the income effect channel. Applied Economics 44(22)2881.

Aoki, M. 1992. Decentralization-Centralization in Japanese Organizations : A Duality Principle. In Kumon, S. \& Rosovsky, H. (eds.). The Political Economy of Japan Vol.3 : Cultural \& Social Dynamics, Stanford University Press, 142-169.

Arezki, Rabah \& Frederick van der Ploeg. 2011. Do Natural Resources Depress Income Per Capita? Review of Development Economics 15(3) 504-521.

Auty, Richard. 1993. Sustaining Development in Mineral Economies: The Resource Curse Thesis

Auty, Richard. 2001. Resource Abundance and Economic Development. Oxford University Press.

Baland, Jean-Marie \& Patrick Francois. 2000. Rent-seeking \& Resource Booms. Journal of Development Economics 61,527-42.

Beason, Richard \& David E. Weinstein. 1996. Growth, Economies of Scale \& Targeting in Japan (19551990). Review of Economics \& Statistics 78(2) 286-295

Beason, Richard \& Dennis Patterson. 2006. The Japan That Never Was: Explaining the Rise and Decline of

${ }^{25}$ Japan's postwar reconstruction is often portrayed as bank and state-led, but recent work tends to qualify the role of banks and recast the state as impeding recovery (Beason and Patterson 2006). The US military government (1945 - 1952) dismantled the zaibatsu into freestanding firms, leaving few business groups. This excision likely left both large banks and the government with relatively more power. Keiretsu business groups arose in the 1950s and 1960s as alliances of legally widely held firms, many former zaibatsu members, thought to be cemented together by numerous small cross-holdings. Most keiretsu) were horizontal (no apex firm) and likely designed to deter takeovers (Sheard 1991), not coordinate investment (Beason and Weinstein 1996). These groups are associated with inefficient investment (Weinstein and Yafeh 1998; Walker 2005) and appear to be unraveling (Lincoln and Shimotani 2009). A few relatively small pyramids persisted or arose in the postwar era. These vertical (capital) keiretsu do not appear to be unraveling. Toyota and other major manufacturers have been reinforcing their pyramidal structures. Both types of keiretsu insulated management from shareholder pressure leaving large banks with broad corporate governance influence, which these used to advance their narrow interests as creditors (Morck et al. 2000). 
a Misunderstood Country. State University of New York Press.

Bebchuk, Lucien, Reinier Kraakman \& George Triantis. 2000. Stock Pyramids, Cross Ownership \& Dual Class equity: The Mechanisms Aand Agency Costs of Separating Control from Cash Flow Rights. In R. Morck ed. Concentrated Corporate Ownership. National Bureau of Economic Research Conference Volume. University of Chicago Press.

Bertrand, M.P., P. Mehra \& S. Mullainathan. 2002. Ferreting out tunneling: an application to Indian business groups. Quarterly Journal of Economics 117, 121-148.

Bhattacharyya, Sambit; Collier, Paul. 2014. Public capital in resource rich economies: is there a curse? Oxford Economic Papers 66(1)1

Bjorvatn, Kjetil, Mohammad Reza Farzanegan \& Friedrich Schneider. 2012. Resource Curse and Power Balance: Evidence from Oil-Rich Countries. World Development 40(7)1308.

Bodea, Cristina, Masaaki Higashijima \& Raju Jan Singh. 2016. Oil and Civil Conflict: Can Public Spending Have a Mitigation Effect? World Development 78 (Feb)1

Boianovsky, Mauro. 2013. Humboldt and the economists on natural resources, institutions and underdevelopment (1752 to 1859). European Journal of the History of Economic Thought 20(1)58.

Bolt, Jutta \& Jan Luiten van Zanden. 2013. The First Update of the Maddison Project; Re-Estimating Growth Before 1820. Maddison Project Working Paper 4.

Boschini, Anne; Pettersson, Jan; Roine, Jesper. 2013. The Resource Curse and its Potential Reversal. World Development 43 (Mar)19

Brückner, Markus. 2010. Natural resource dependence, non-tradables, and economic growth. Journal of Comparative Economics 38(4)461-471.

Bryant, H.B. \& Stratton, S.S. 1871. Bryant \& Stratton's common school book-keeping: embracing single \& double entry, containing sixteen complete sets of books, with ample exercises \& illustrations for primary schools \& academies. New York: Ivison, Phinney, Blakeman \& Co.; Chicago: S.C. Griggs \& Co. (Originally published in 1869).

Buonanno, Paolo, Ruben Durante, Giovanni Prarolo \& Paolo Vanin. 2015. Poor Institutions, Rich Mines: Resource Curse in the Origins of the Sicilian Mafia. Economic Journal 125(586)F175.

Busse, Matthias \& Steffen Gröning. 2013. The resource curse revisited: governance and natural resources Public Choice 154(1,2)1-20.

Choe, Bong-Chan Kho \& René M. Stulz. 1999. Do Foreign Investors Destabilize Stock Markets? The Korean Experience in 1997. Journal of Financial Economics 54(2) 227-264

Claessens Stijn, Simeon Djankov, Larry H.P. Lang. 2000. "The separation of ownership \& control in East Asian Corporations," Journal of Financial Economics 58(1-2), 81-112.

Claessens, Stjin, Simeon Djankov, Joseph Fan \& Larry Lang. 2002. Expropriation of minority shareholders in East Asia. Journal of Finance 57 2741-2771.

Cockx, Lara; Francken, Nathalie. 2016. Natural resources: A curse on education spending? Energy Policy 92(May)394

Corden, W. Max and J. Peter Neary. 1982. Booming sector and de-industrialisation in a small open economy. Economic Journal 92(368)825-848.

Cotet, Anca \& Kevin Tsui. 2013. Oil, Growth, and Health: What Does the Cross-Country Evidence Really Show? Scandinavian Journal of Economics 115(4)1107-1137.

Cust, James \& Steven Poelhekke.2015. The Local Economic Impacts of Natural Resource Extraction. Annual Review of Resource Economics 7 (1)251

Davis, Graham A. 1995. Learning to love the Dutch disease: Evidence from the mineral economies. World development 23(10)1765-1779.

Davis, Graham. 2013. Replicating Sachs and Warner's Working Papers on the Resource Curse. Journal of Development Studies 49(12)1615 
Diamond, Larry \& Jack Mosbacher. 2013. Petroleum to the People: Africa's Coming Resource Curse-and How to Avoid It. Foreign Affairs 92(5)86-98.

Drehlichman, Maurico. 2005. All that Glitters: Precious Metals, Rent Seeking and the Decline of Spain. European Review of Economic History 9(3)313-36

Easterly, William. 2006. The Big Push Deja Vu: A Review of Jeffrey Sach's The End of Poverty: Economic Possibilities for Our Time. Journal of Economic Literature 44(1) 1.

Elbadawi, Ibrahim Ahmed \& Raimundo Soto. 2015. Resource rents, institutions, and violent civil conflicts. Defence and Peace Economics 26(1)89.

Ellman, Michael. 1981. Natural Gas, restructuring and re-industrialisation: the Dutch experience of industrial policy. In T. Barker and V. Brailovsky, eds. Oil or Industr, 149-166, Academic Press.

Farzanegan, Mohammad Reza. 2014. Can oil-rich countries encourage entrepreneurship? Entrepreneurship and Regional Development 26(9,10)706

Flynn, Dennis O. \& Arturo Giraldez. 2002. Cycles of Silver: Global Economic Unity through the MidEighteenth Century. Journal of World History 13, 391-427.

Forsyth, Peter and John Kay. 1980. The economic implications of North Sea oil revenues. Fiscal Studies 1(3)1-28.

Fruin, W. Mark. 1992. The Japanese Enterprise System: Competitive Strategies \& Cooperative Structures. Oxford University Press, New York.

Fukuzawa, Yukichi. 1873. Chuai no hou (Methods of bookkeeping), (in Japanese). Tokyo: Keio University Press. (Published in four volumes in $1873 \& 1874$.)

Gilberthorpe, E. \& E. Papyrakis. 2015. The extractive industries \& development: The resource curse at the micro, meso \& macro levels. The Extractive Industries and Society 2 381-390

Guilló, Maria Dolores \& Fidel Perez-Sebastian. 2015. Neoclassical growth \& the natural resource curse puzzle. Journal of International Economics 97(2)423

Haber, Stephen \& Victor Menaldo. 2011. Do Natural Resources Fuel Authoritarianism? A Reappraisal of the Resource Curse. American Political Science Review 105(1)1-26

Haber, Stephen. 2000. Political Institutions \& Economic Growth in Latin America: Essays in Policy, History \& Political Economy. Hoover Institution Press.

Haber, Stephen. 2002. Crony Capitalism \& Economic Growth in Latin America: Theory \& Evidence. Hoover Institution Press

Haslam, Paul Alexander. 2016. Overcoming the Resource Curse: Reform and the Rentier State in Chile and Argentina, 1973-2000. Development and Change 47(5)1146.

Hatakeyama, H. 1988. Formation of Sumitomo Zaibatsu (Sumitomo zaibatsu seiritsushi no kenkyu), (in Japanese), Dobunkan Shuppan, Tokyo.

Havranek, Tomas, Roman Horvath, and Ayaz Zeynalov. 2016. Natural resources and economic growth: A meta-analysis. World Development 88, 134-151.

Henry, Peter Blair. 2000a. Do stock market liberalizations cause investment booms? Journal of Financial Economics 58(1/2) 301.

Henry, Peter Blair. 2000b. Stock market liberalization, economic reform \& emerging market equity prices. Journal of Finance 55(2) 529-62.

Henry, Peter Blair. 2003. Capital-account liberalization, the cost of capital \& economic growth. American Economic Review 93(2) 91.

Hitotsubashi. 2003. History of double entry book keeping in Japan. (In Japanese). Hitotsubashi University Library, Tokyo. Available from: http://www.lib.hitu.ac.jp/service/tenji/pamphlet/pamphlet_15.pdf

Holden, Steinar. 2013. Avoiding the resource curse the case Norway. Energy Policy 63(Dec)870

Innis, Harold. (1923) A History of the Canadian Pacific Railway. Revised edition (1971). Toronto: University of Toronto Press. 
Innis, Harold. (1930) The Fur Trade in Canada: An Introduction to Canadian Economic History. Toronto: University of Toronto Press.

Innis, Harold. (1940) The Cod Fisheries: The History of an International Economy. Toronto: The Ryerson Press.

Innis, Harold. (1956) Essays in Canadian Economic History, edited by Mary Q. Innis. Toronto: University of Toronto Press.

Ishii, K., Japan's industrialization \& zaibatsu, in Japanese, Tokyo, Iwanami, 1992.

James, Alexander. 2015. The resource curse: A statistical mirage? Journal of Development Economics 114(May)55

Japan Oil, Gas and Metals National Corporation. 2006. History of Copper Business, Tokyo.

Johnson, Simon, Rafael La Porta, Florencio Lopez-de-Silanes \& Andrei Shleifer. 2000. "Tunneling," American Economic Review 90(2), May, 22-27.

Kaplan, Steven, \& Bornudette A. Minton. 1994. Appointments of outsiders to Japanese boards: Detrminants and implications for managers. Journal of Financial Economics 36 (2), 225-258.

Kasuya, M., The beginning \& modification of bonus payments to directors in Japan, (in Japanese), CIRJE discussion paper series CIRJE-J-152, University of Tokyo, 2006.

Keay, lan. 2015. Immunity from the resource curse? The long run impact of commodity price volatility: evidence from Canada, 1900-2005. Cliometrica 9(3)333-358.

Khanna, Tarun \& J. Rivkin. 2001. Estimating the Performance Effects of Business Groups in Emerging Markets. Strategic Management Journal 22(1) 45-74.

Khanna, Tarun \& Raymond Fisman. 2004. Facilitating Development: The Role of Business Groups. World Development 32(4) 609-628.

Kobayashi, M., Japan's industrialization \& privatization of government enterprises (Nihon no kogyoka to kangyo haraisage), (in Japanese), Toyo Keizai, Tokyo, 1977.

Kobayashi, M., Mitsubishi's control of the Takashima coal mine, which was purchased from Goto Shojiro, Kanto Gakuin Univ. Economics Papers, Volume 215, April 2003, 71-87.

Kobayashi, M., Zaibatsu \& coal mines: Mitsubishi coal mines, (in Japanese), Kanto Gakuin Univ. Economics Papers, 1979, 62-73.

Kozan Konwakai (Ed.). 1993. History of the Development of Japan's Mining Industries, (in Japanese), Vol.2. Kozan Konwakai (Ed.), Hara Publishers, Tokyo,

Krueger, A.O., 1974. The Political Economy of the Rent-Seeking Society. American Economic Review 64, 13

Krueger, Anne. 1974. The Political Economy of the Rent-Seeking Society. American Economic Review 64 291-303.

La Porta, Rafael, Florencio Lopez-De-Silanes, Andrei Shleifer, Robert W Vishny. 1997a. Legal determinants of external finance. Journal of Finance 52(3) 1131-1150.

La Porta, Rafael, Florencio Lopez-de-Silanes, Andrei Shleifer, Robert W Vishny. 1997. Trust in large organizations. American Economic Review 87(2) 333-338.

Lincoln, J. and Shimotani, M. 2009. Whither the Keiretsu, Japan's Business Networks? How Were They Restructured? What Did They Do? Why Are They Gone? National University of Singapore Working Paper.

Lipton, David and Jeffrey Sachs. 1990. Privatization in Eastern Europe: the case of Poland. Brookings papers on economic activity 1990(2)293-341.

López-de-Silanes, Florencio. 1997. Determinants of privatization prices. Quarterly Journal of Economics 112(4)965-1025.

Matheis, Mike. 2016. Local Economic Impacts of Coal Mining in the United States 1870 to 1970. Journal of Economic History 76(4)1152-1181

Mavrotas, George, Syed Mansoob Murshed \& Sebastian Torres, 2011. Natural Resource Dependence 
and Economic Performance in the 1970-2000 Period. Review of Development Economics15(1)124-138.

McMaster, John. 1963. The Takashima mine: British capital and Japanese industrialization. Business History Review 37(3) 217-239.

Mehlum, Halvor, Karl Moene \& Ragnor Torvik. 2006. Institutions and the Reource Curse. Economic Journal 116,1-20.

Mendoza, Ronald U.; MacArthur, Harold J.; Ong Lopez, Anne Beline. 2015. Devil's excrement or manna from heaven? A survey of strategies in natural resource wealth management. International Journal of Development Issues; Bingley 14(1)2-25

Mishima, Y. (ed.). 1981. The Mitsubishi Zaibatsu, (in Japanese), Nikkei, Tokyo.

Mitchell, Brian. 2003. International Historical Statistics: Africa, Asia \& Oceania, 1750-2000, 4th ed. Basingstoke \& New York: Palgrave Macmillan.

Mitchell, Brian. 2003a. International Historical Statistics: Americas, 1750-2000, 4th ed. Basingstoke \& New York: Palgrave Macmillan.

Mitchell, Brian. 2003b. International Historical Statistics: Europe, 1750-2000, 4th ed. Basingstoke \& New York: Palgrave Macmillan.

Miyajima, H. 2004. Economic history of industrial policy \& corporate governance: micro analysis of Japanese economic development. (In Japanese.) Yuhikaku, Tokyo.

Morck, Randall \& Bernard Yeung. 2004. Family Control \& the Rent-Seeking Society. Entrepreneurship Theory \& Practice 19. 391-409.

Morck, Randall \& Masao Nakamura. 2005. A Frog in a Well Knows Nothing of the Ocean: A History of Corporate Ownership in Japan. In Randall Morck, ed. A History of Corporate Governance around the World: Family Business Groups to Professional Managers. University of Chicago Press. 367459

Morck, Randall \& Masao Nakamura. 2007. Business Groups \& the Big Push: Meiji Japan's Mass Privatization \& Subsequent Growth. Enterprise \& Society 8, 543-601.

Morck, Randall, Daniel Wolfenzon \& Bernard Yeung. 2005. Corporate Governance, Economic Entrenchment \& Growth. Journal of Economics Literature 43 657-722.

Mori, Shuzo. Takashima coal mine history: From the coal discovery to Mitsubishi as its owner (in Japanese). Journal of Hōsei Historical Society 26, 1973, 94-106.

Morikawa, Hidemasa. 1980. Zaibatsuno keieishiteki kenkyu (Business history research of zaibatsu), (in Japanese), Toyo Keizai, Tokyo.

Morikawa, Hidemasa. 1992. Zaibatsu: the rise \& fall of family enterprise groups in Japan, University of Tokyo Press, Tokyo.

Murphy, Kevin M., Andrei Shleifer \& Robert Vishny. 1991. The Allocation of Talent: Implications for Growth. Quarterly Journal of Economics. May. 503-530.

Murphy, Kevin, Andrei Shleifer \& Robert Vishny 1993. Why is Rent-seeking Costly to Growth? American Economic Review 82(2) 409-414.

Murphy, Kevin., Andrei Shleifer \& Robert Vishny. 1989. Industrialization \& the Big Push. Journal of Political Economy 97 1003-1026.

Oishi, N., Relation between the business \& the fund of early Mitsubishi, (in Japanese), Japan Business History Review 40, December 2005, 3-26.

Okazaki, T. 1933, Japanese Industrialization \& the Steel Industry (nihon no kogyoka to tekko sangyo), (in Japanese), University of Tokyo Press.

Papyrakis, Elissaios and Ohad Raveh. 2014. An Empirical Analysis of a Regional Dutch Disease: The Case of Canada. Environmental and resource economics 58(2)179-98.

Papyrakis, Elissaios. 2017. The Resource Curse - What Have We Learned from Two Decades of Intensive Research: Introduction to the Special Issue. Journal of Development Studies 53(2)175-185 
Prebisch, Raul. 1959. Commercial policy in the underdeveloped countries. American Economic Review 49(2)251-273.

Rajan, Raghuram \& Luigi Zingales. 2003. The great reversals: the politics of financial development in the twentieth century. Journal of Financial Economics 69(1) 5-50.

Reischauer, Edwin O. 1988. The Japanese Today: Change \& Continuity. Harvard University Press (Belknal Press): Cambridge, MA.

Robinson, James, Ragnar Torvik \& Thierry Verdier. 2006. Political Foundations of the Resource Curse. Journal of Development Economics 79(2)447-68.

Rodriguez, Francisco \& Jeffrey D. Sachs. 1999. Why do resource-abundant economies grow more slowly? Journal of Economic growth 4(3)277-303.

Rosenstein-Rodan, Paul. 1943. Problems of Industrialization of Eastern \& South Eastern Europe. Economic Journal 53

Ross, M. 2014. What have we learned about the resource curse? (mimeo) UCLA

Ross, Michael L. 2011. Will Oil Drown the Arab Spring? Democracy and the Resource Curse. Foreign Affairs 90(5)2-7.

Sachs, Jeffrey D. 1990. Charting Poland's Economic Rebirth." Challenge 33(1)22-30.

Sachs, Jeffrey D. 2005. The End of Poverty: Economic Possibilities for Our Time. Penguin Press: New York.

Sachs, Jeffrey D., and Andrew M. Warner. 1999. Natural resource intensity and economic growth. In: Chambers B, Farooq A, Mayer J, eds. Development policies in natural resource economies. Edward Elgar, Cheltenham, 13-38.

Sachs, Jeffrey D., and Andrew M. Warner. 2001. The curse of natural resources." European economic review 45(4)827-838.

Sheard, Paul. 1991. The economics of interlocking shareholding in Japan. Ricerche Economiche 45, 42148.

Shimada, R. 2006. Comparative analysis of international copper trade in the 18th century," (18 seiki niokeru kokusai doboeki no hikakubinseki), Waseda University Journal of Political Economy 362 54-70.

Shimme, Shinichiro 1937. Introduction of double-entry book keeping into Japan. Accounting Review, 12, 290-295.

Shleifer, Andrei \& Robert Vishny. 1989. Management Entrenchment: The Case of Manger-Specific Investments. Journal of Financial Economics 25 123-139.

Shleifer, Andrei \& Robert Vishny. 1994. Politicians \& Firms. Quarterly Journal of Economics 109(4) 9951025.

Smith, Brock. 2015. The resource curse exorcised: Evidence from a panel of countries. Journal of Development Economics 116 (Sep )57

Stulz, René \& Rohan Williamson. 2003. Culture, Openness \& Finance. Journal of Financial Economics 70(3) 313-349.

Sugiyama, Shinya. 2012. Japanese Economic History: Recent historical \& contemporary periods. (In Japanese.) Iwanami Shoten, Tokyo.

Takada, Haruhito. 2013. Codefication of Japanese Commercial Code in Meiji Era. (in Japanese.) The Quarterly Review of Corporation Law \& Society, Vol.9-4 (Issue 34), February 2013, 60-74.

Tang, John P. 2011. Technological leadership and late development: evidence from Meiji Japan, 1868 - 1912. Economic History Review, 64, S1, pp. 99-116.

Torres, Nuno, Oscar Afonso \& isabel Soares. 2013. Natural Resources, Wage Growth and Institutions - a Panel Approach. World Economy 36(5)661.

Torvik, Ragnar. 2002. Natural Resources, Rent Seeking \& Welfare. Journal of Development Economics 67,455-70. 
Udagawa, M. 1976. New Zaibatsu (Shinko zaibatsu). In S. Yasuoka (ed.), Japanese zaibatsu (Nihonno zaibatsu), Nikkei, Tokyo, 107-144.

Van Der Ploeg, Frederick; Poelhekke, Steven. 2017. The Impact of Natural Resources: Survey of Recent Quantitative Evidence. Journal of Development Studies 53(2)205-216.

Ville, Simon \& Olav Wicken. 2013. The dynamics of resource-based economic development: evidence from Australia and Norway. Industrial and Corporate Change 22(5)1341.

Walker, M. 2005. Industrial Groups and Investment Efficiency. Journal of Business 78: 1973 - 2001.

Weinstein, David and Yishay Yafeh. 1998. On the Costs of a Bank-Centered Financial System: Evidence from the Changing Main Bank Relations in Japan. Journal of Finance 53: 635 - 672.

Williams, Andrew. 2011. Shining a Light on the Resource Curse: An Empirical Analysis of the Relationship Between Natural Resources, Transparency, and Economic Growth. World Development 39(4)490.

Yasuoka, Shigeaki, ed. 1976. Japanese zaibatsu (Nihonno zaibatsu). Nikkei, Tokyo.

Yasuoka, Shigeaki. 1982. Mitsui Zaibatsu. (in Japanese), Nikkei, Tokyo.

Zingales, Luigi \& Raghuram Rajan. 2003. Saving Capitalism from the Capitalists. Princeton University Press. 
Table 1. Output from major copper producing countries, 1621-1800

\begin{tabular}{|c|c|c|c|c|c|}
\hline \multicolumn{2}{|c|}{$\underline{\text { Japan }}$} & \multicolumn{2}{|c|}{$\underline{\text { Chile }}$} & \multicolumn{2}{|c|}{ England } \\
\hline period & tons per yr & Period & tons per yr & period & tons per yr \\
\hline \multirow[t]{2}{*}{$1621-1715$} & 2,500 & $1671-1700$ & 75 & & \\
\hline & & $1701-1720$ & 100 & & \\
\hline \multirow[t]{2}{*}{$1716-1754$} & 2,240 & $1721-1740$ & 250 & $1726-1754$ & 927 \\
\hline & & $1741-1760$ & 300 & & \\
\hline 1755-1839 & 1,920 & $1761-1800$ & 1,000 & $1755-1800$ & 3,481 \\
\hline
\end{tabular}


Table 2. Copper production and exports by Japan and Sweden, 1701 to 1800.

Exports are actual exported amounts, not amounts contracted for. The latter are thought to have fallen short of the former towards the 1800 s as the Tokugawa regime diverted copper to domestic use.

\begin{tabular}{|c|c|c|c|c|c|}
\hline & \multicolumn{3}{|c|}{ Japan } & \multicolumn{2}{|c|}{ Sweden } \\
\hline & \multirow[b]{2}{*}{ Production } & \multicolumn{2}{|c|}{ Exports } & \multirow[b]{2}{*}{ Production } & \multirow[b]{2}{*}{ Exports } \\
\hline & & $\begin{array}{c}\text { Dutch East } \\
\text { India Co. }\end{array}$ & $\begin{array}{c}\text { Chinese } \\
\text { merchants }\end{array}$ & & \\
\hline $1701-10$ & 5,340 & 912 & 2,930 & unknown & unknown \\
\hline $1711-20$ & 3,840 & 609 & 1,904 & unknown & unknown \\
\hline $1721-30$ & unknown & 597 & unknown & 830 & 334 \\
\hline $1731-40$ & unknown & 541 & unknown & 793 & 309 \\
\hline $1741-50$ & unknown & 594 & unknown & 863 & 191 \\
\hline $1751-60$ & unknown & 660 & 1,154 & 839 & 324 \\
\hline $1761-70$ & 2,873 & 554 & 1,047 & 715 & 303 \\
\hline $1771-80$ & 2,702 & 559 & 897 & 892 & 516 \\
\hline $1781-90$ & unknown & 454 & 962 & 1,153 & 616 \\
\hline $1791-1800$ & unknown & 217 & 578 & 890 & 422 \\
\hline
\end{tabular}

Source: Shimada (2006, Table 1, p.55). 
Table 3. Privatization Qs of Major Firms in Japan's Mass Privatization Program

The privatization of Takashima served as a template for the mass privatization of the 1880s and 1890s. Privatization Proceeds are in current yen and sterling, the latter to adjust for the yen's depreciation relative to the gold standard. Privatization Qs are proceeds from the privatization in sterling divided by book value, which reflects the historical cost of state investment in each SOE. Book values are available for Dec 1885, and are converted to sterling at the 1985 exchange rate.

\begin{tabular}{|c|c|c|c|c|c|c|}
\hline \multirow{2}{*}{$\begin{array}{l}\text { Sold } \\
\text { Nov-74 }\end{array}$} & \multirow{2}{*}{$\begin{array}{l}\text { State-owned Enterprise } \\
\text { Takashima Coal Mine }\end{array}$} & \multicolumn{2}{|l|}{ Mine } & \multicolumn{2}{|c|}{$\begin{array}{c}\text { Privatization } \\
\text { Proceeds }\end{array}$} & \multirow{2}{*}{$\begin{array}{c}\text { Privatization } \\
\mathbf{Q} \\
1.161\end{array}$} \\
\hline & & Yes & $¥$ & 550,000 & $£ 114,400$ & \\
\hline Jun-82 & Hiroshima Cotton Spinning & No & $¥$ & 12,570 & f 2,325 & 0.217 \\
\hline Jan-83 & Aburato Coal Mine & Yes & $¥$ & 27,943 & f 5,169 & 0.538 \\
\hline Jul-84 & Nakakosaka Iron Ore & Yes & $¥$ & 28,575 & f 5,201 & 0.318 \\
\hline Jul-84 & Cement Manufacturing & No & $¥$ & 61,741 & f 11,237 & 0.691 \\
\hline Jul-84 & \& Fukagawa Shirorengaishi & No & $¥$ & 12,121 & f 2,206 & 0.691 \\
\hline Oct-84 & Nashimotomura Shirorengaishi & No & $¥$ & 101 & 18 & $\mathrm{n} / \mathrm{a}$ \\
\hline Aug-84 & Kosaka Silver Mine & Yes & $¥$ & 273,659 & $£ 49,806$ & 0.475 \\
\hline Dec-84 & Innai Silver Mine & Yes & $¥$ & 108,977 & f 18,853 & 0.155 \\
\hline Mar-85 & Ani Copper Mine & Yes & $¥$ & 337,766 & f 58,434 & 0.202 \\
\hline May-85 & Shinagawa Glass & No & $¥$ & 79,950 & f 13,831 & 0.272 \\
\hline Jun-85 & Daikatsu Makiyama Gold Mine & Yes & $¥$ & 117,142 & f 20,266 & 0.783 \\
\hline Nov-86 & Aichi Cotton Spinning & No & $¥$ & 79,104 & f 12,578 & $\mathrm{n} / \mathrm{a}$ \\
\hline Dec-86 & Sapporo Brewery & No & $¥$ & 27,672 & f 4,400 & $\mathrm{n} / \mathrm{a}$ \\
\hline May-87 & Shinmachi Textile (Silk) & No & $¥$ & 141,000 & f 22,419 & 1.104 \\
\hline Jun-87 & Nagasaki Shipbuilding & No & $¥$ & 459,000 & f 72,981 & 0.442 \\
\hline Jul-87 & Hyogo Shipbuilding & No & $¥$ & 188,029 & f 29,897 & 0.251 \\
\hline Dec-87 & Kamaishi Iron Ore & Yes & $¥$ & 12,600 & f $\quad 2,003$ & 0.006 \\
\hline Jan-88 & Mita Ag. Tools Mfg. & No & $¥$ & 33,795 & $f \quad 5,171$ & $\mathrm{n} / \mathrm{a}$ \\
\hline Mar-88 & Banshu Vineyard & No & $¥$ & 5,477 & 838 & 0.774 \\
\hline Aug-88 & Miike Coal Mine & Yes & & ,590,439 & f 702,337 & 6.856 \\
\hline Nov-89 & Hornai Coal Mine \& RR & Part & $¥$ & 352,318 & f 55,314 & 0.169 \\
\hline Mar-90 & Monbetsu Sugar Beets & No & $¥$ & 994 & 171 & 0.004 \\
\hline Sep-93 & Tomioka Textiles (Silk) & No & $¥$ & 121,460 & f 15,304 & 0.538 \\
\hline Sep-96 & Sado Gold Mine & Yes & $¥ 1$ & 600,000 & $£ 171,200$ & 1.823 \\
\hline
\end{tabular}

Table 4. Privatization Qs for Mines versus Other SOEs

Privatization Qs are proceeds from the privatization in sterling divided by book value, which 
reflects the historical cost of state investment in each SOE. Book values are available for Dec 1885 , and are converted to sterling at the 1985 exchange rate.

\section{All SOEs SOE Mines All Other SOEs}

\begin{tabular}{|c|c|c|c|c|}
\hline Equal weighted mean privatization $\mathrm{Q}$ & 0.832 & 1.21 & & 0.500 \\
\hline Proceeds-weighted mean privatization $\mathrm{Q}$ & 0.967 & 1.06 & & 0.286 \\
\hline Standard deviation of privatization Qs & 1.45 & 2.19 & & 0.31 \\
\hline Maximum privatization $\mathrm{Q}$ & 6.86 & 6.86 & & 1.16 \\
\hline Minimum privatization $\mathrm{Q}$ & 0.004 & 0.004 & & 0.155 \\
\hline Privatization proceeds in total $f$ & $1,396,358$ & f $1,175,326$ & $f$ & 221,033 \\
\hline Privatization proceeds as percent of total & $100 \%$ & $84 \%$ & & $16 \%$ \\
\hline Number of privatizations ${ }^{26}$ & 21 & 10 & & 10 \\
\hline
\end{tabular}

${ }^{26}$ One privatized SOE, Hornai Coal Mines and Railroad, was in both mining and other sectors. 
Table 5. Total asset shares (\%) of Mitsui, Mitsubishi and Sumitomo zaibatsu group firms within the top 100 firms in each industry

\begin{tabular}{|c|c|c|c|c|c|}
\hline \multicolumn{2}{|l|}{ Industry } & 1896 & 1914 & 1919 & 1929 \\
\hline \multicolumn{2}{|l|}{ Mining } & 90.1 & 64.3 & 57.1 & 63.9 \\
\hline \multirow{9}{*}{ All other sectors } & Metals & 24.5 & 33.9 & 46.4 & 43.2 \\
\hline & Iron And Steel & --- & 84.5 & 41.7 & 51.4 \\
\hline & $\begin{array}{l}\text { Transportation } \\
\text { Machinery }\end{array}$ & 69.5 & 15.5 & 30.7 & 20.9 \\
\hline & Electric, Machinery & --- & 58.5 & 28.4 & 28.7 \\
\hline & Chemicals & --- & --- & 20.5 & 13.7 \\
\hline & Pottery & 14.3 & 21.5 & 16.6 & 32.0 \\
\hline & Paper, Pulp & 38.0 & 40.4 & 41.0 & 35.8 \\
\hline & Textiles & 8.1 & 17.3 & 13.8 & 14.6 \\
\hline & Fishing, Food & & 20.3 & 17.5 & 25.6 \\
\hline \multicolumn{2}{|c|}{ Total (all industries) } & 34.0 & 28.3 & 28.5 & 28.3 \\
\hline \multicolumn{2}{|c|}{ Total assets ( $x 1$ million yen) } & 79.1 & 799.1 & 2550.0 & 4797.2 \\
\hline
\end{tabular}


Table 6. The Mitsubishi Pyramidal Group's Apex Firm in 1935

Sources of dividends and interest paid to the Mitsubishi apex firm, and its equity and debt investments, by Mitsubishi zaibatsu member firm as of 1935 . Asterisks indicate first tier subsidiaries of the apex firm. Other firms are in lower tiers of the pyramid.

\begin{tabular}{|c|c|c|c|c|c|}
\hline \multirow{2}{*}{\multicolumn{2}{|c|}{ Mitsubishi zaibatsu firms }} & \multicolumn{2}{|c|}{$\frac{\text { Dividends plus }}{\text { Interest }}$} & \multicolumn{2}{|c|}{ Investment stake } \\
\hline & & $x ¥ 1,000$ & $\%$ & $x ¥ 1,000$ & $\%$ \\
\hline \multirow[t]{11}{*}{ Mitsubishi Mining' } & & 4,946 & $34 \%$ & 43,381 & $24 \%$ \\
\hline & Mitsubishi Bank* & 2,493 & $17 \%$ & 31,160 & $17 \%$ \\
\hline & $\begin{array}{l}\text { Mitsubishi Heavy } \\
\text { Industry* }\end{array}$ & 2,213 & $15 \%$ & 30,867 & $17 \%$ \\
\hline & Mitsubishi Corp* & 1,356 & $9 \%$ & 22,500 & $12 \%$ \\
\hline & Mitsubishi Electric* & 1,325 & $9 \%$ & 13,500 & $7 \%$ \\
\hline & Mitsubishi Warehouses* & 21 & $0 \%$ & 10,000 & $6 \%$ \\
\hline & Tokio Marine Ins & 1,202 & $8 \%$ & 7,513 & $4 \%$ \\
\hline & Nippon Iron/Steel & 371 & $3 \%$ & 5,938 & $3 \%$ \\
\hline & Mitsubishi Oil* & 0 & $0 \%$ & 2,100 & $1 \%$ \\
\hline & Nippon Yusen (NYK) & 99 & $1 \%$ & 2,023 & $1 \%$ \\
\hline & Meiji Life & 0 & $0 \%$ & 1,950 & $1 \%$ \\
\hline \multirow{12}{*}{$\begin{array}{l}\text { All other } \\
\text { Mitsubishi firms }\end{array}$} & Mitsubishi Steel & 55 & $0 \%$ & 1,446 & $1 \%$ \\
\hline & Mitsubishi Trust* & 79 & $1 \%$ & 1,313 & $1 \%$ \\
\hline & Ryoka Warehousing & 0 & $0 \%$ & 1,009 & $1 \%$ \\
\hline & JVC & 200 & $1 \%$ & 909 & $1 \%$ \\
\hline & Tawao Industries & 0 & $0 \%$ & 480 & $0 \%$ \\
\hline & Wakamatsu Chikuko & 43 & $0 \%$ & 440 & $0 \%$ \\
\hline & $\begin{array}{l}\text { Manchuria Takushoku } \\
\text { Public Corp }\end{array}$ & 0 & $0 \%$ & 390 & $0 \%$ \\
\hline & Nippon Kokusan Kogyo & 0 & $0 \%$ & 379 & $0 \%$ \\
\hline & Nanyo Pearls & 45 & $0 \%$ & 300 & $0 \%$ \\
\hline & Kyushu Transmission Lines & 17 & $0 \%$ & 281 & $0 \%$ \\
\hline & Other & 42 & $0 \%$ & 2,558 & $1 \%$ \\
\hline & Total & 14,507 & $100 \%$ & 180,435 & $100 \%$ \\
\hline
\end{tabular}


Figure 1. State Control over Japanese Mining Prior to the Mass Privatization

Percentage of mining output attributable to state-controlled mines

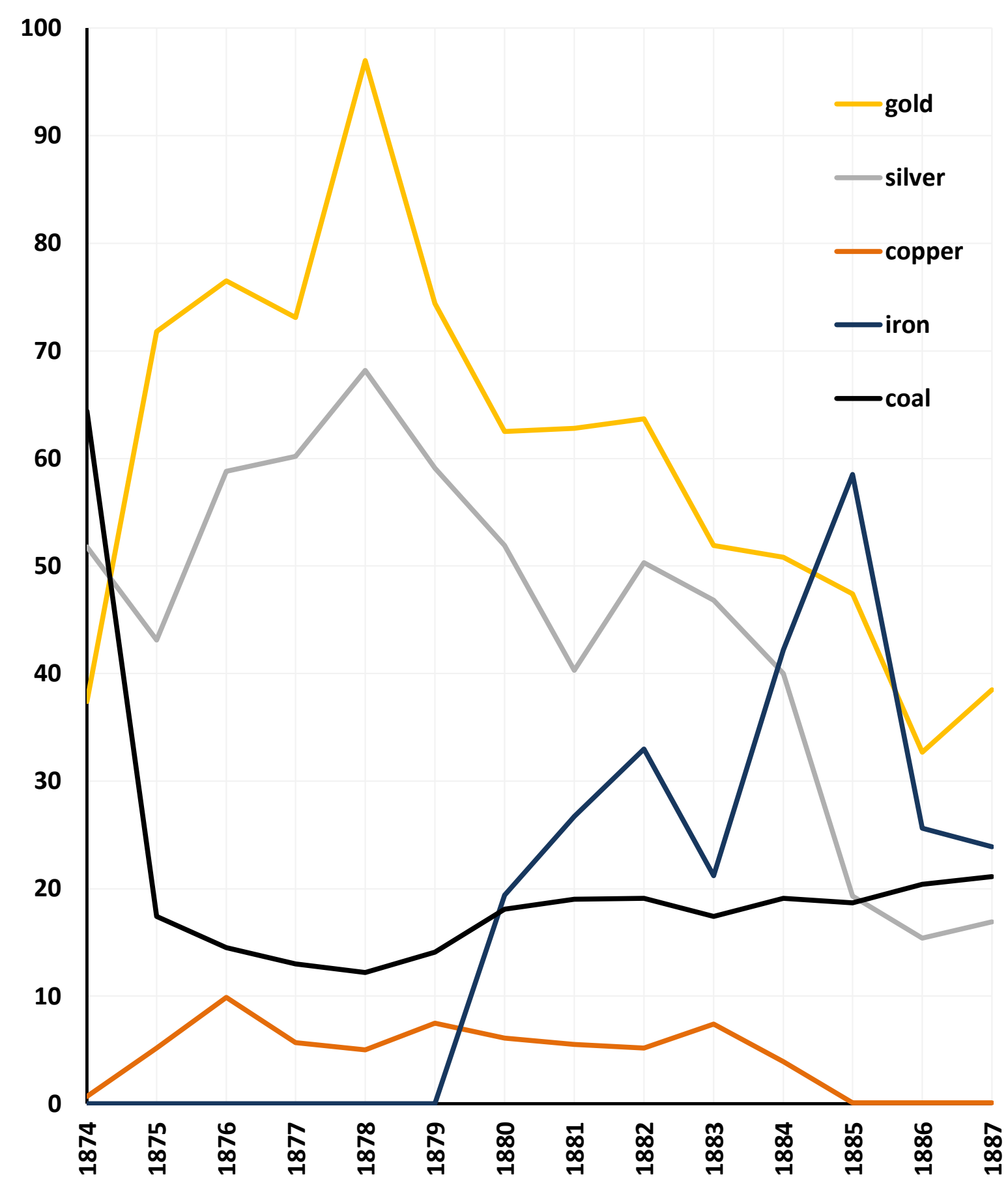

Source: Kozan Konwakai (1993) 
Figure 2. World's Largest Minerals Producers - Late $19^{\text {th }}$ to Early $20^{\text {th }}$ Century

Panel A. Coal (Thousands of Metric tons, logarithmic scale)

For USA and UK all forms of coal, hard coal only for other countries.

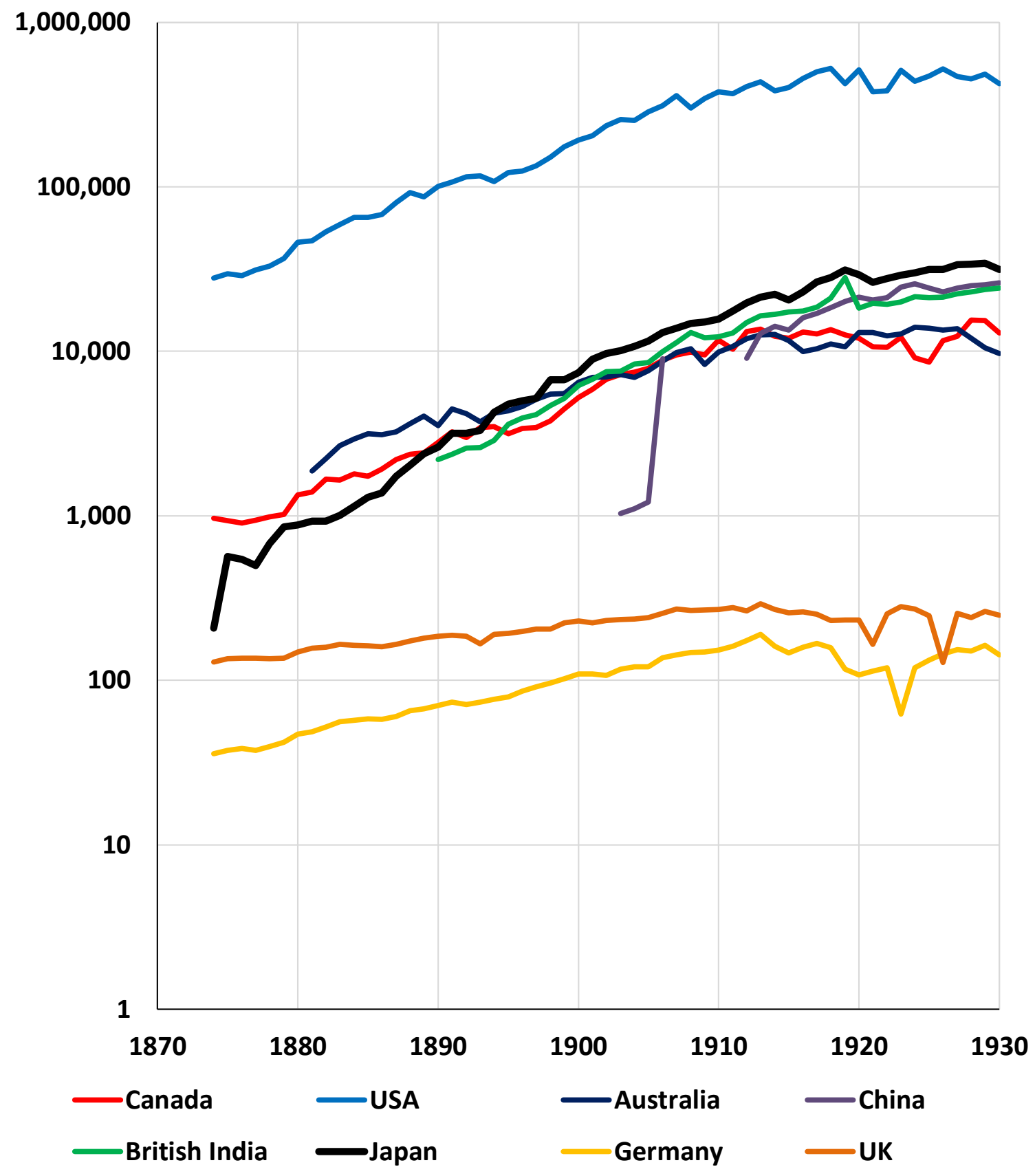


Panel B. Copper (Thousands of Metric Tons, logarithmic scale)

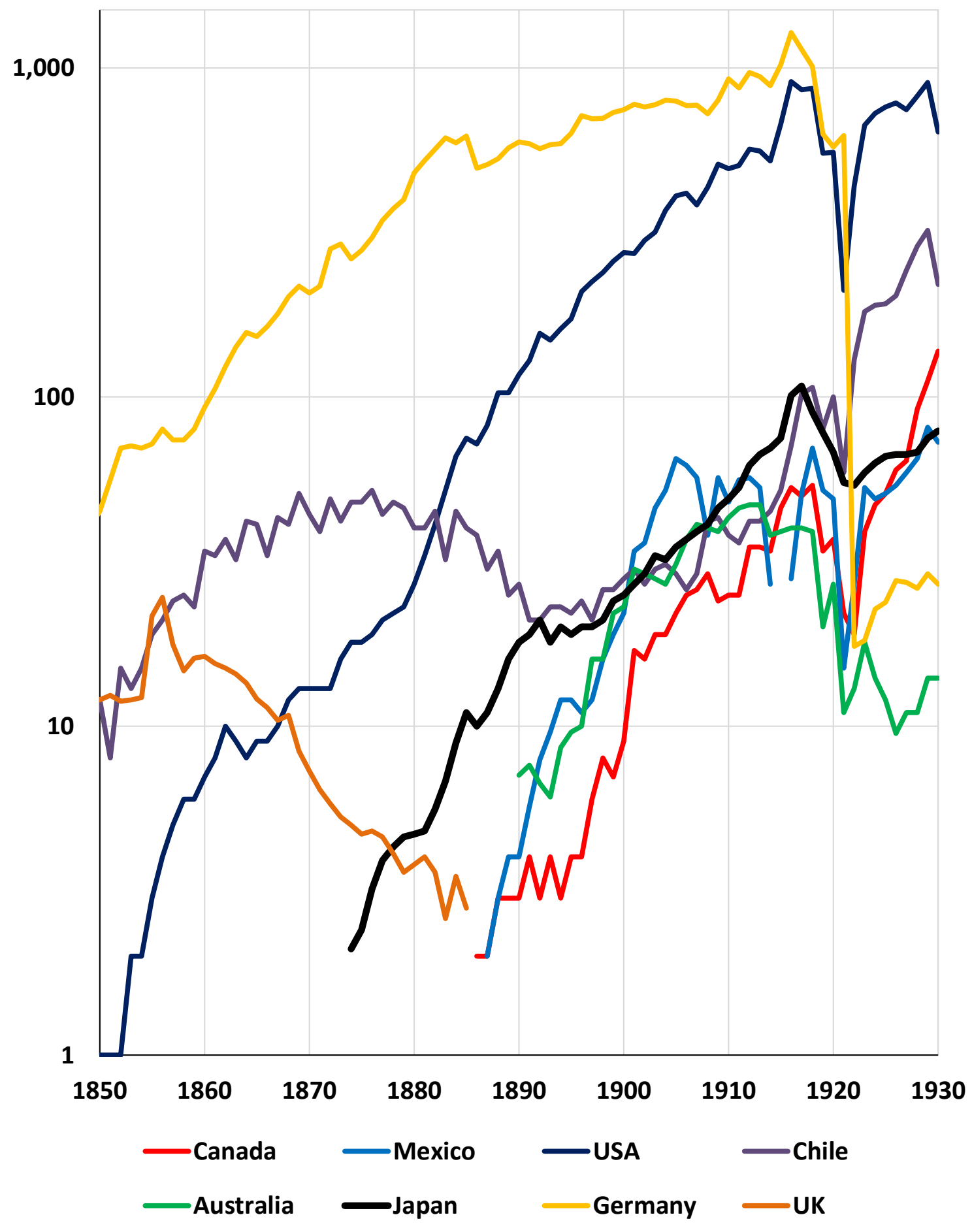


Panel C. Gold Production (Metric Tons, logarithmic scale)

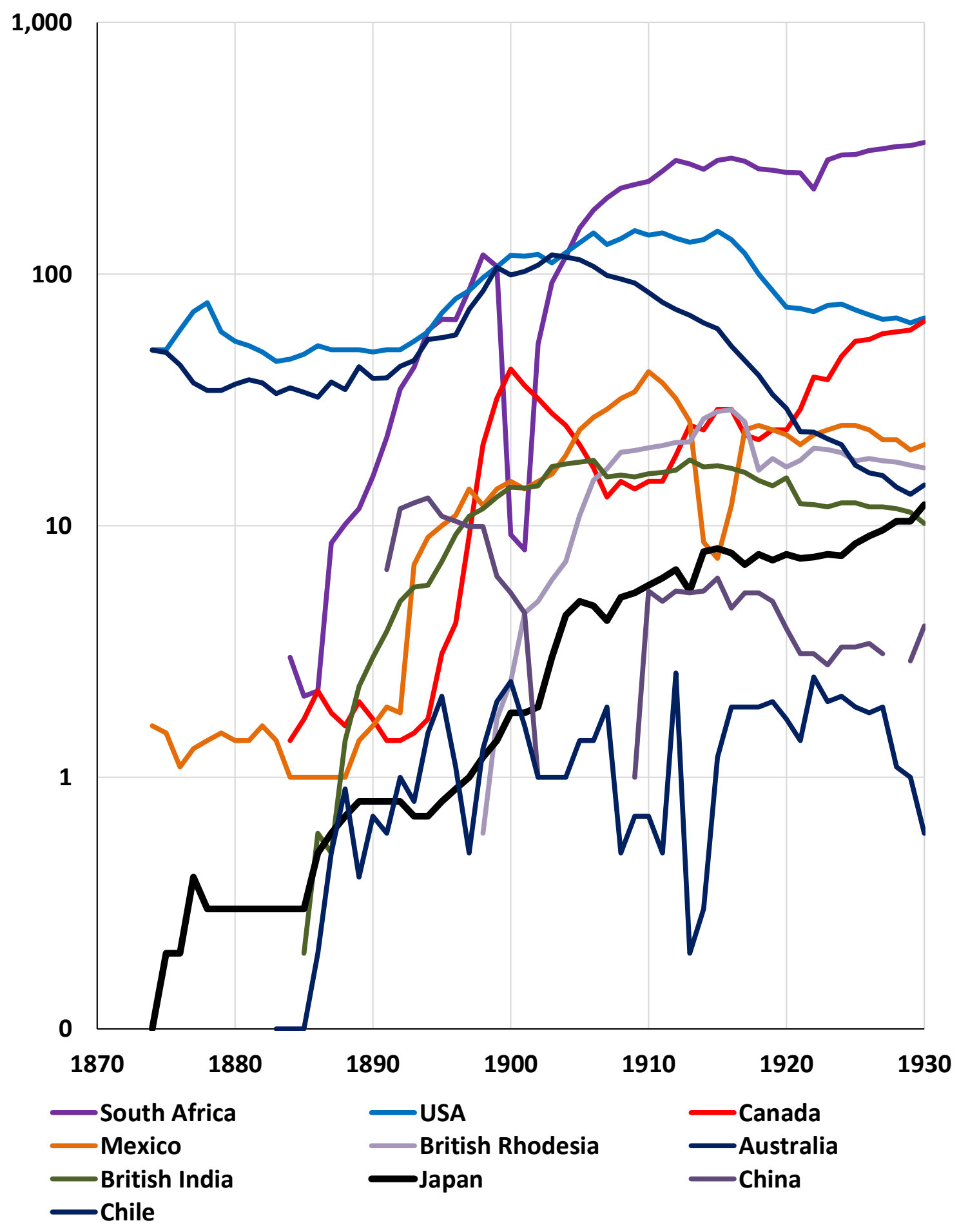


Panel D. Iron Ore (Thousands of Metric Tons, logarithmic scale)

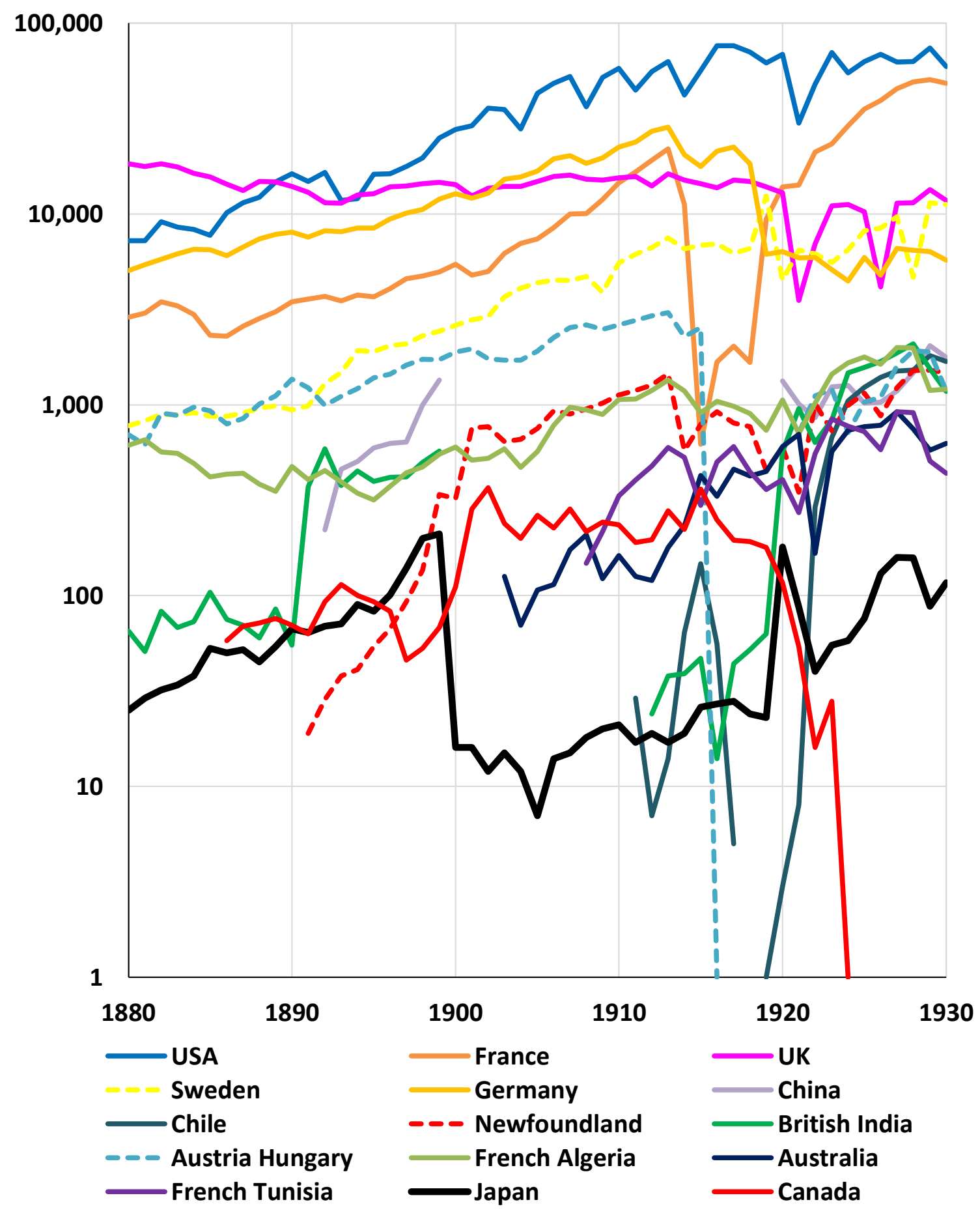


Panel E. Silver (Metric Tons, logarithmic scale)

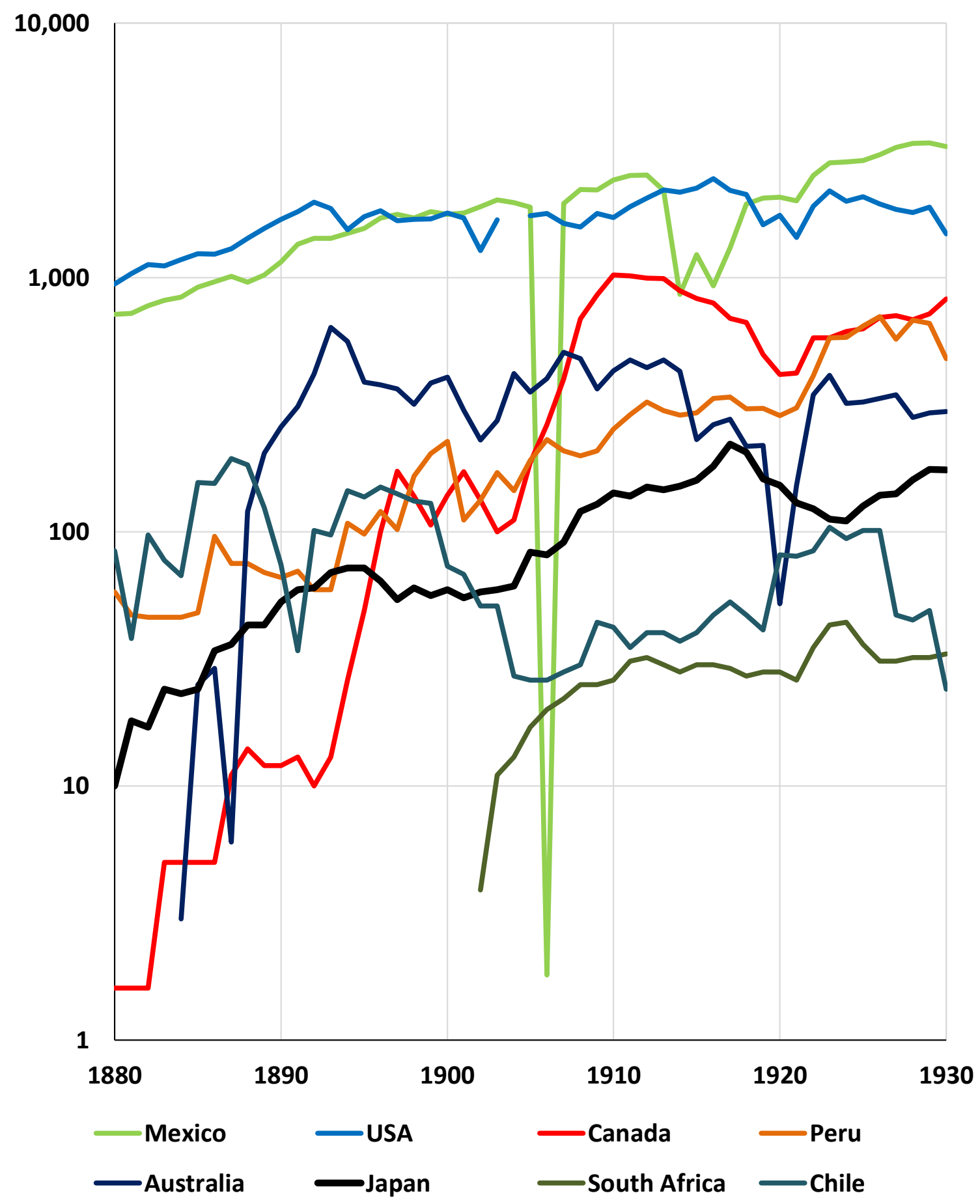

Source: International Historical Statistics 


\section{Figure 3. Generic Pyramidal Structure of a Zaibatsu Business Group}

The great zaibatsu that arose after the mass privatization assumed the form of pyramidal business groups: a family controlled apex firm holds equity control blocks of a first tier of subsidiaries, each of which can hold equity control blocks in a set of second tier subsidiaries, each of which can hold control blocks in member firms in yet another tier of subsidiaries, and so on. Shares that are not part of these control blocks are owned by small shareholders, who typically cannot oppose the directives of the controlling family, regardless of the number of tiers of firms through which those directives are relayed. The structure, though predominantly financed with public equity capital, magnifies a modest family fortune into control over a large group of firms worth far more, all the while preserving undisputable family control over all firms in the pyramid. Common variations from this archetypical form include cross-holdings (firms holding shares in other firms in the same tier, or in firms in higher tiers) and public shareholders owning stock in the apex firm (important in the Nissan zaibatsu only).

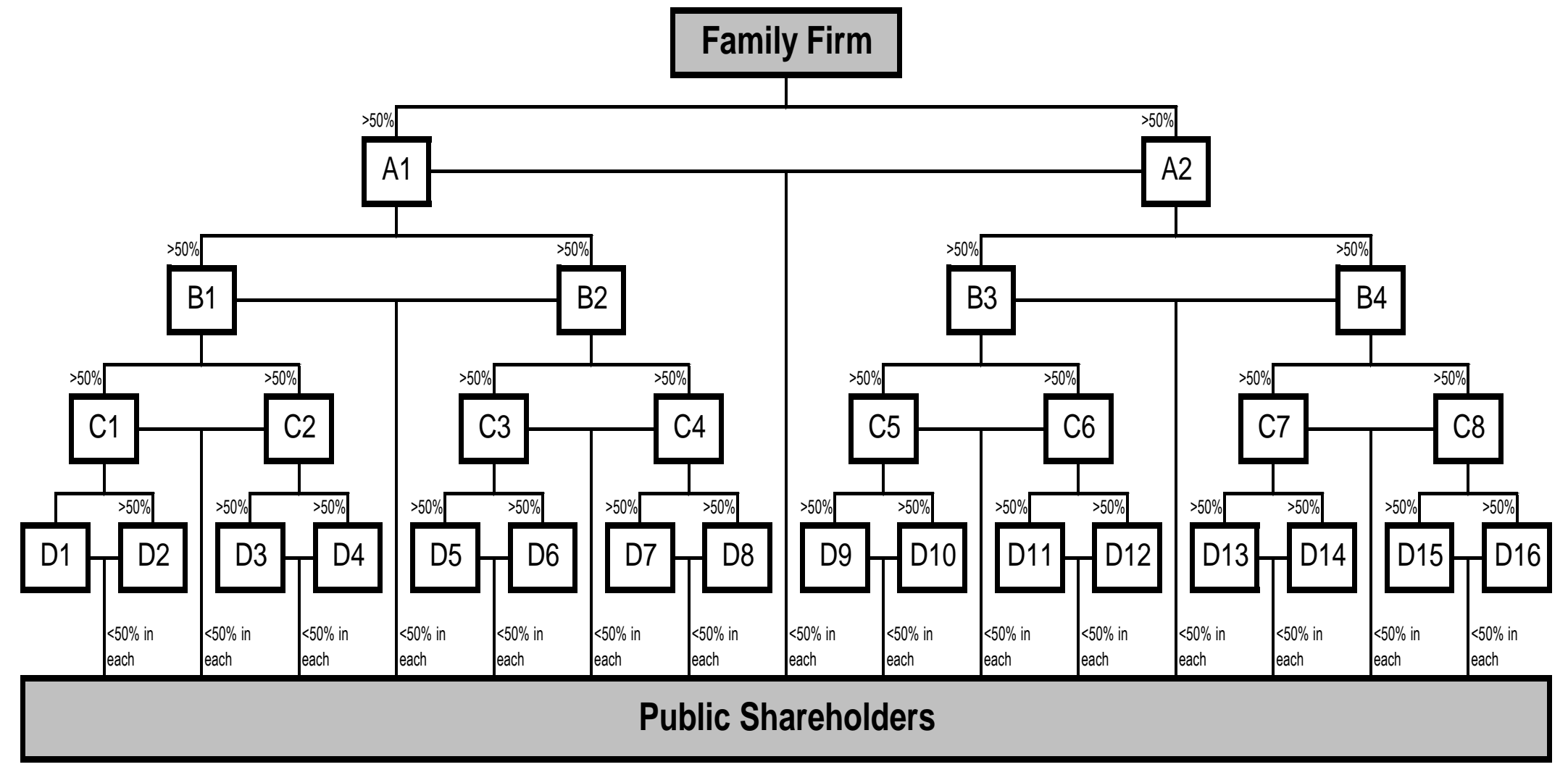


Figure 4. Fraction of Mitsui group firms' revenues from mining versus other sectors.

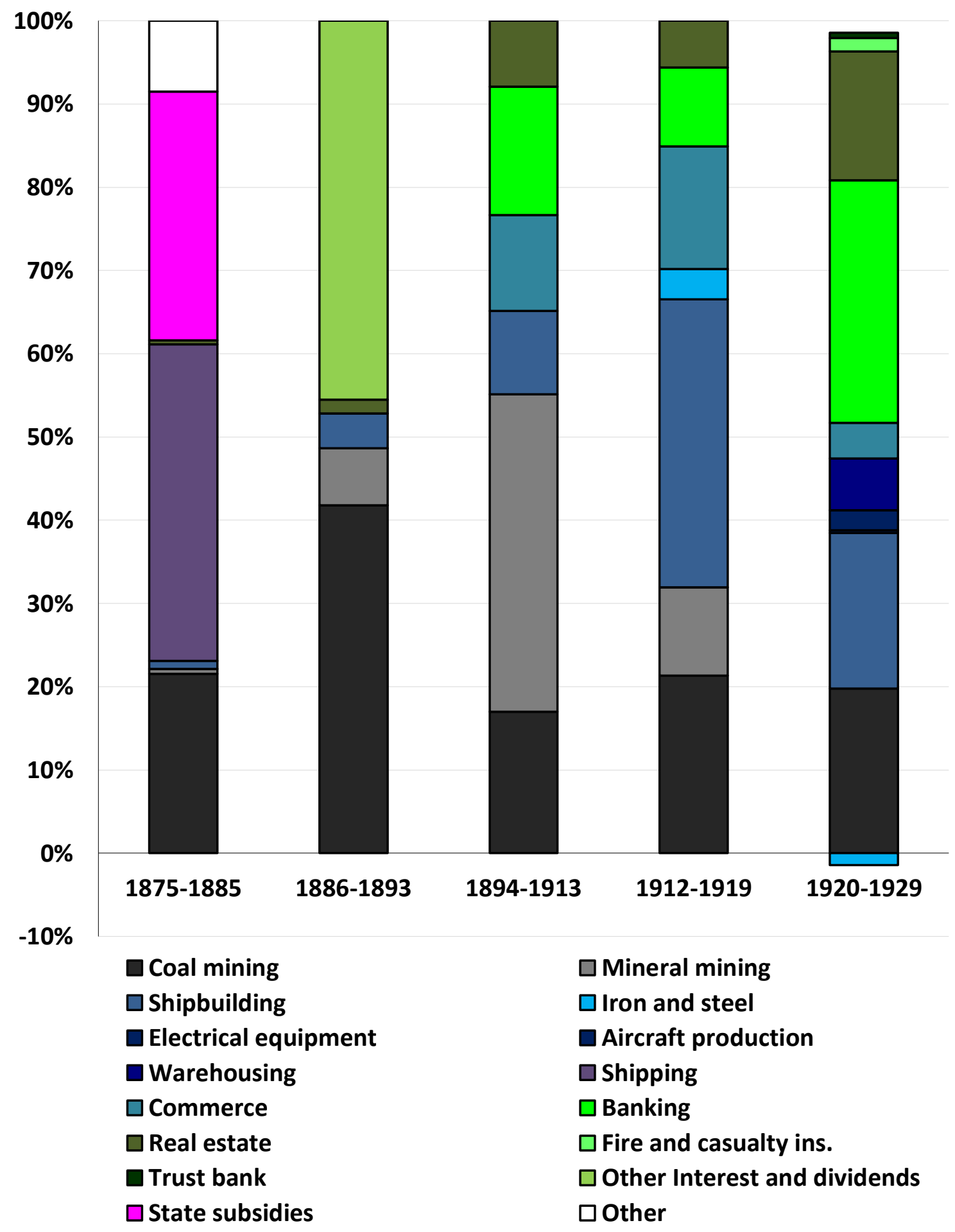

Source: Miyajima (2004). 
Figure 5. The Importance of Natural Resources in the Sumitomo Zaibatsu

Beshi Copper Mine contributed a large fraction of the total earnings of all Sumitomo firms until well into the $20^{\text {th }}$ century.

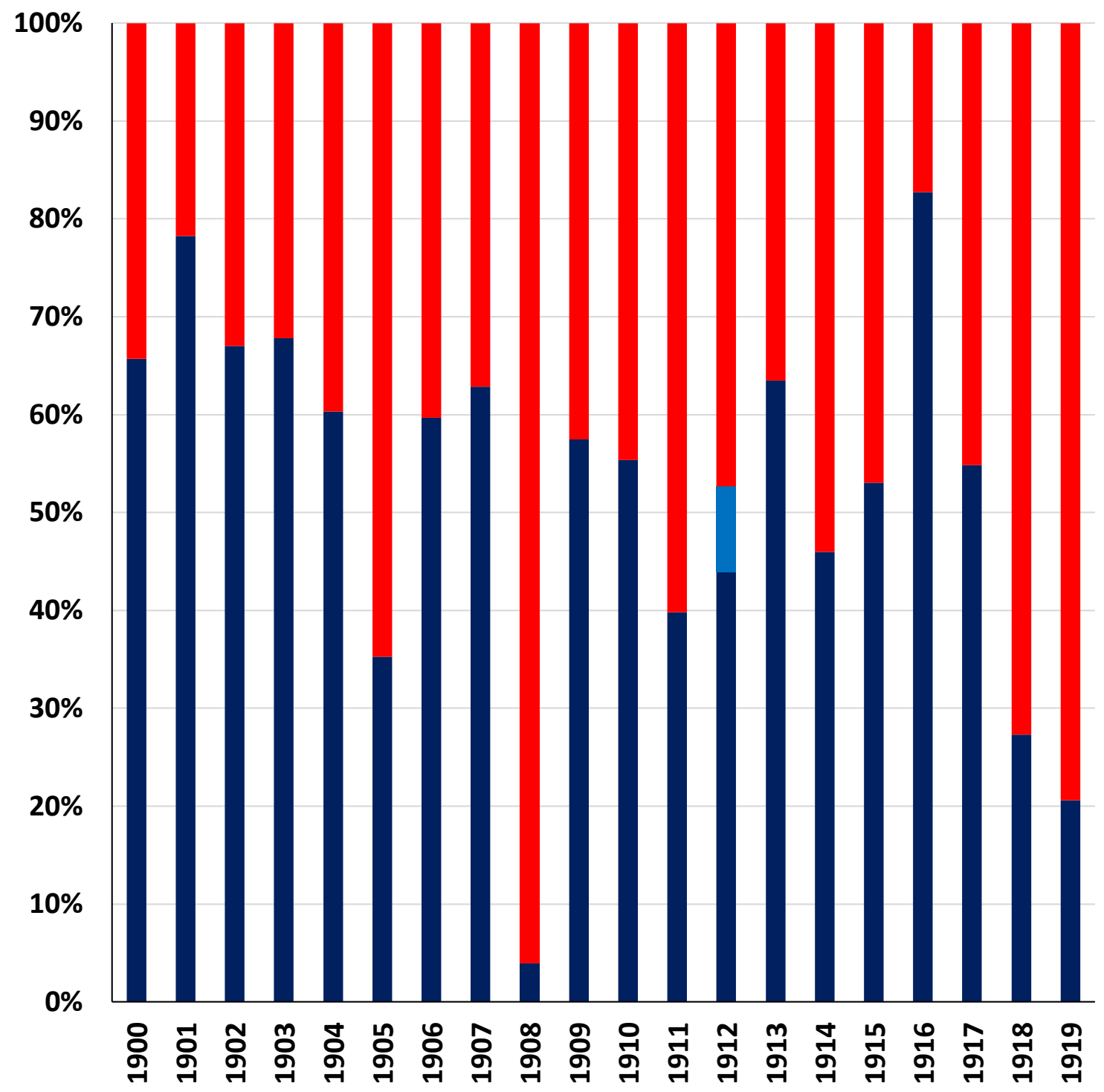

Besshi Copper Mines Other Sumitomo mining firms All other Sumitomo firms 
Figure 6. The Sumitomo Zaibatsu in 1928

By 1928, Beshi Copper Mine, together with the group's two other mining firms, contributed only about 5\% of the zaibatsu's total earnings.

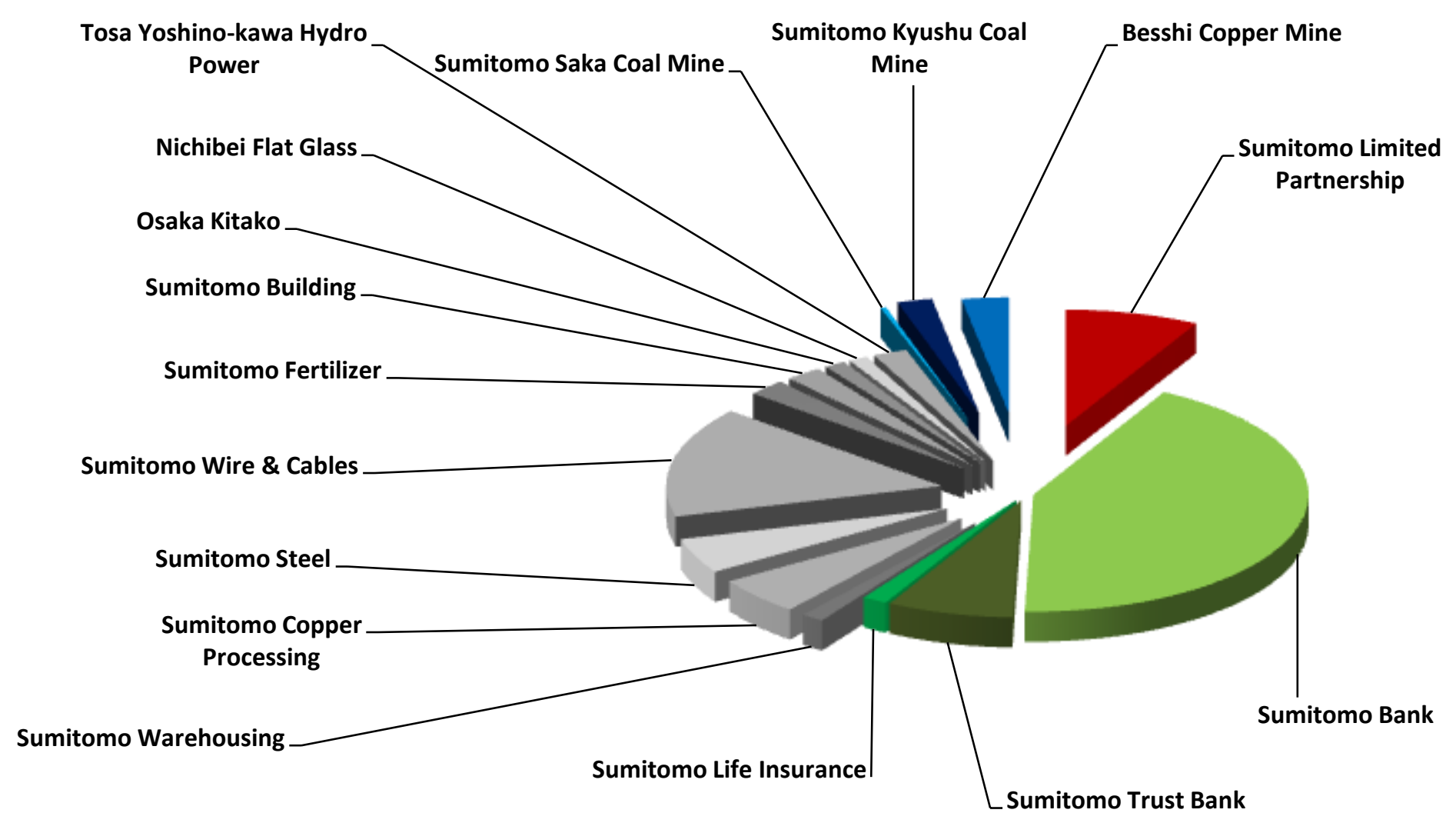

Source: Miyajima (2004) 
Figure 7. Aikawa's Diagram of the Nissan Pyramidal Group

Capital is pumped from the public capital tub at the bottom up to the operating subsidiaries at the top - directly, through the Nissan holding company tub in the center, or through the financial institutions tub at the lower right. By turning one-way and bidirectional values, Aikawa could adjust the level of capital in each operating subsidiary to its needs, subsidizing weak but necessary units with the overall profits of the industrially diversified group.

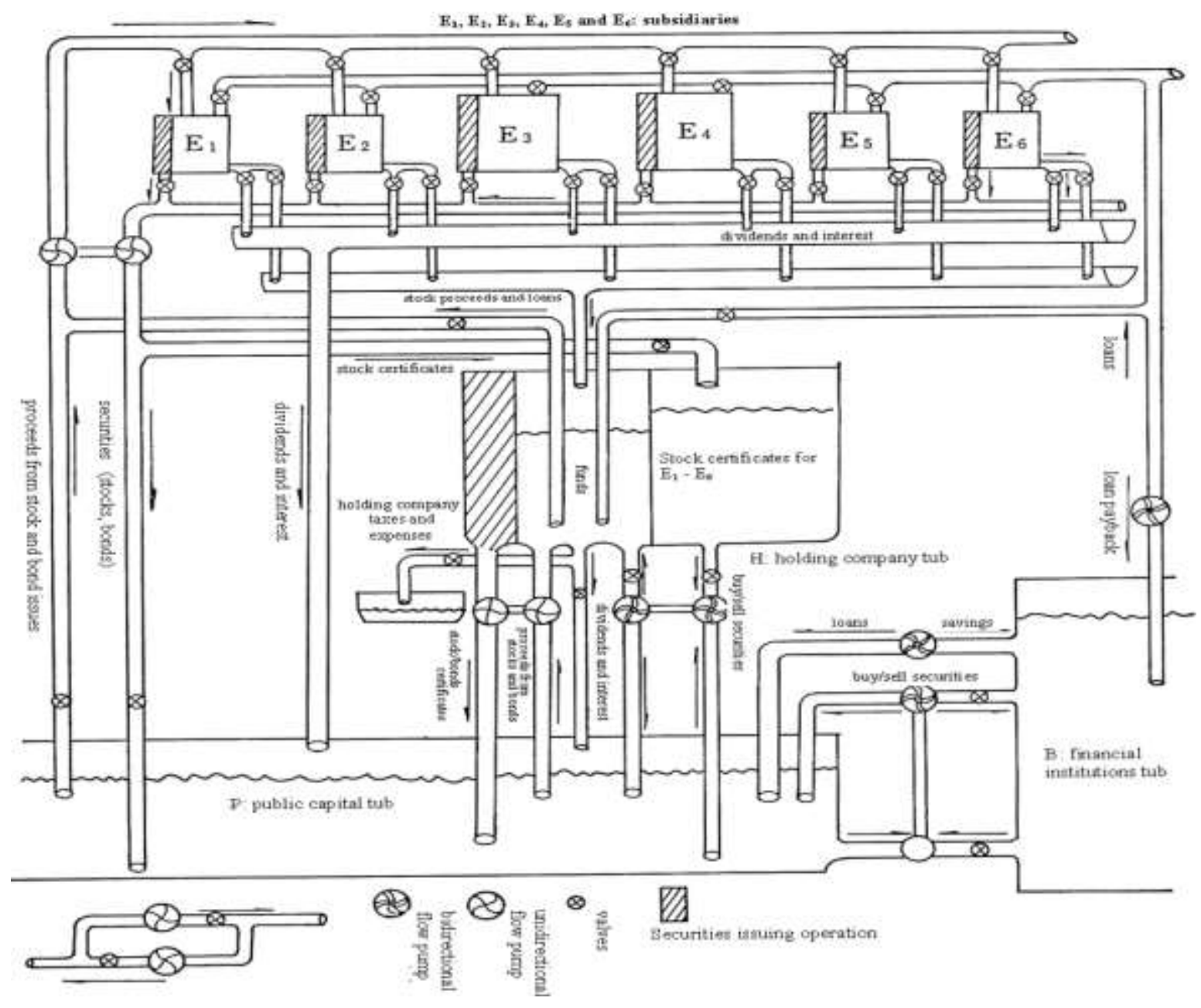

Source. Aikawa (1934), translations by Morck and Nakamura (2005). 
Figure 8. Real Per Capita Gross Domestic Product

Real per capita GDP in constant 1990 US dollars for Japan and selected other countries

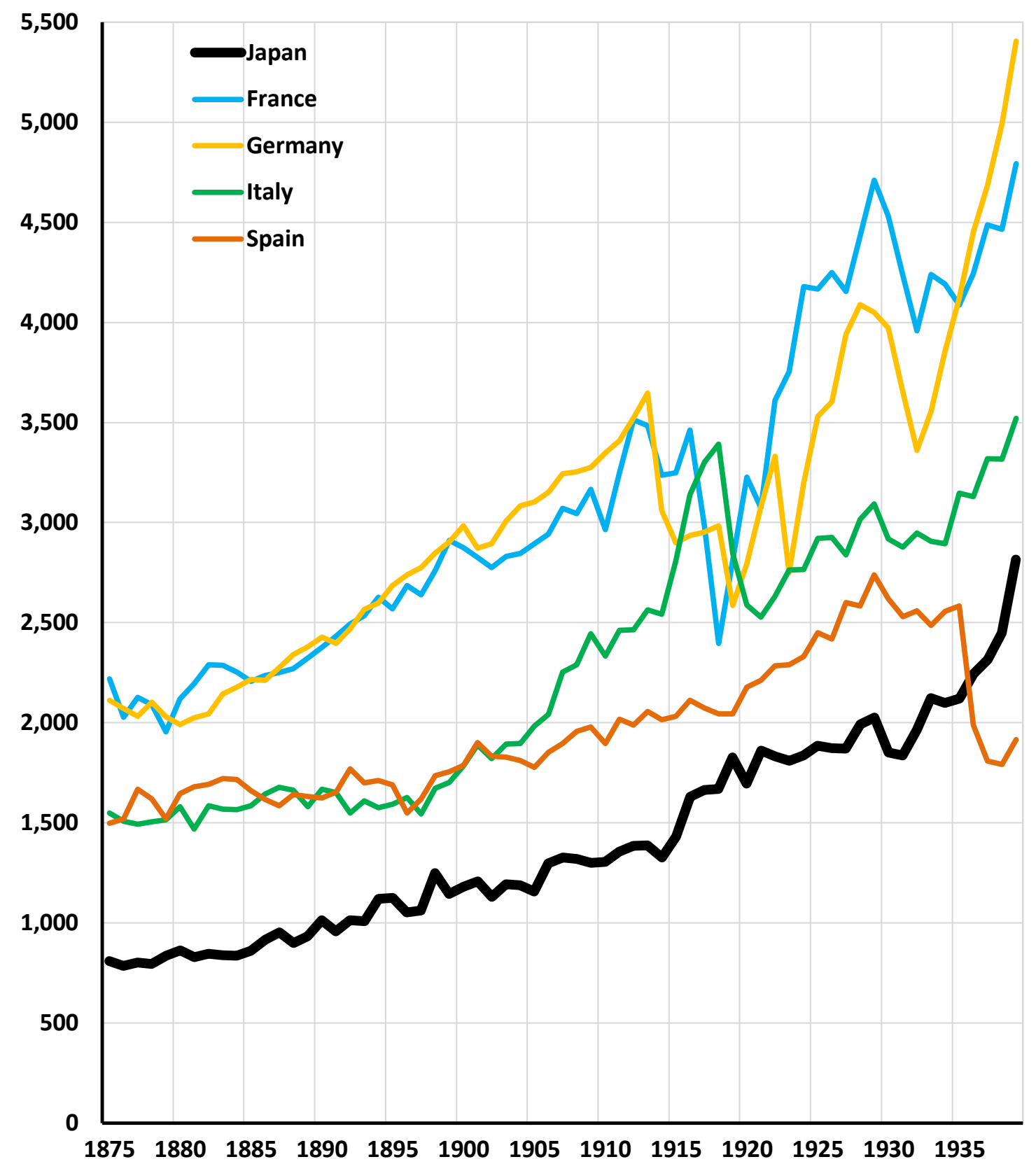

Source. Madison, Angus Historical Statistics for the World Economy (Bolt and van Zanden, 2013) 
Figure 9. The Decline of Mining as Industrialization Proceeds, 1908 to 1937

Each industry's production in yen, as percent of total industrial production by largest sectors in 1937

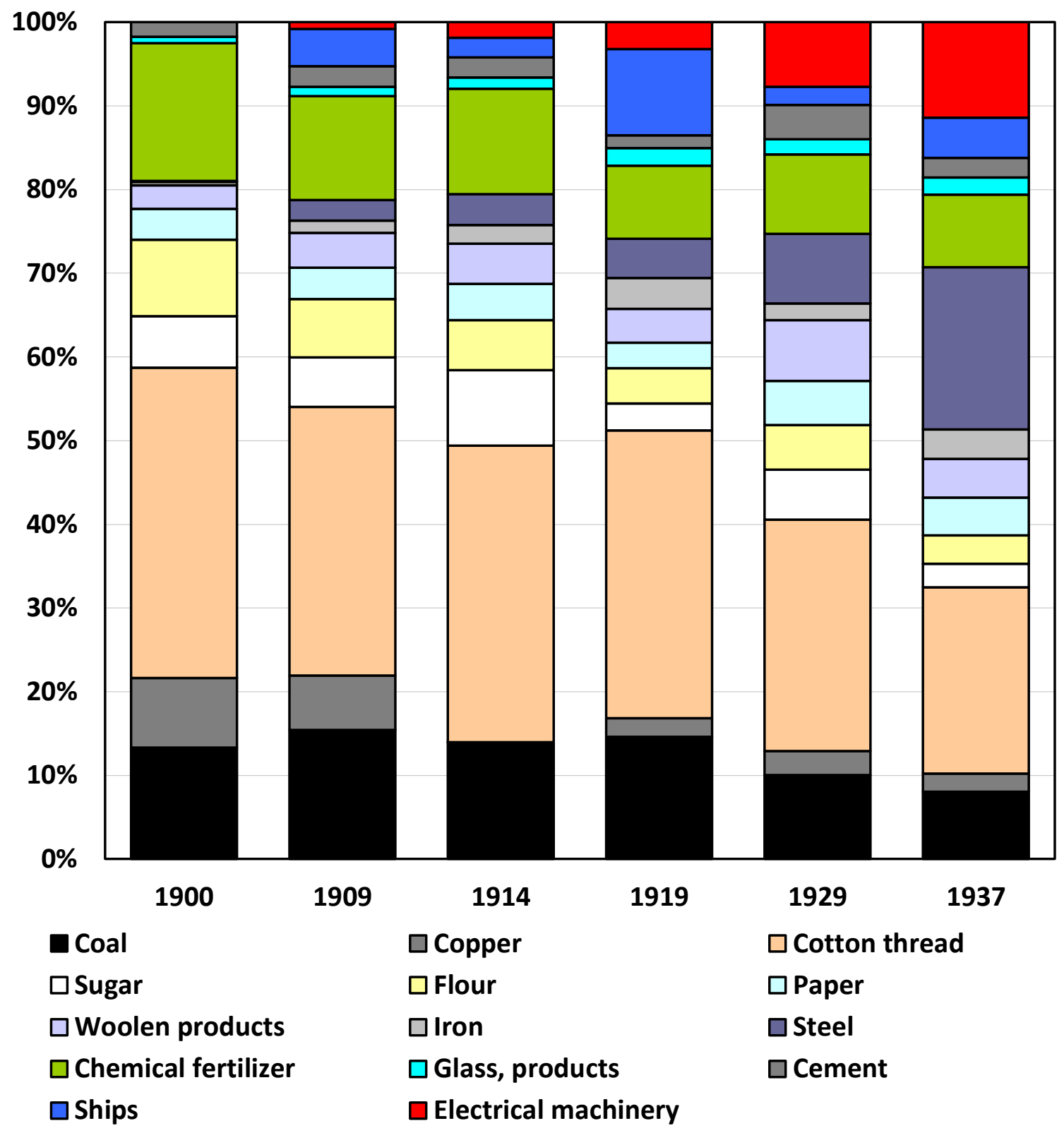

Source: Based on data in Miyajima (2004, p.26) 
Figure 10. Public sector versus private sector pay scales (real 1934-36 yen)

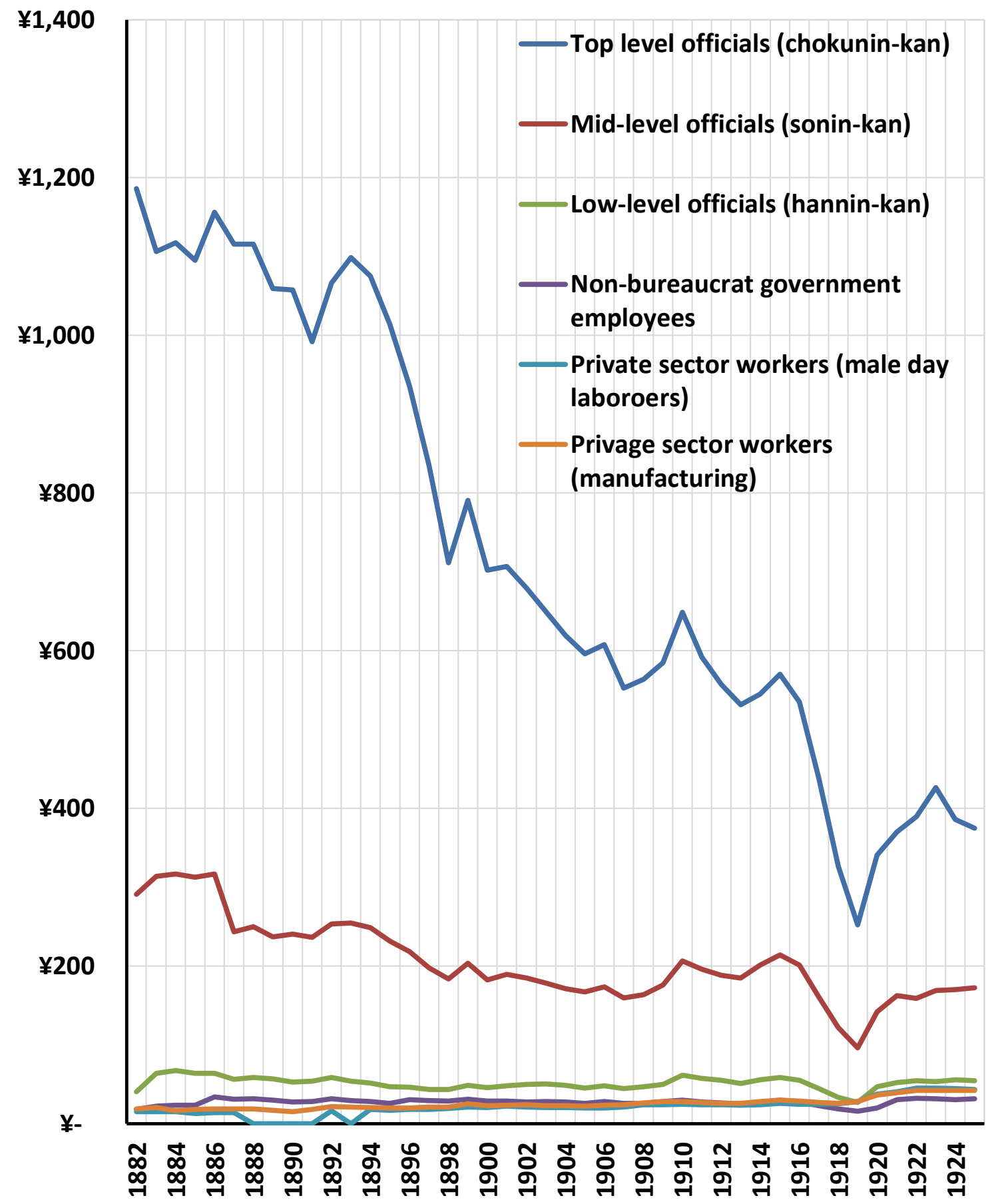

